\title{
From Benign Anarchy to Divine Anarchy: A Critical Review of "Spiritual Anarchism"
}

Anthony Fiscella

Independent Scholar, Sweden

Rather than assuming that such a thing as "spiritual anarchism" exists (a union of two highly contested terms), this chapter critically examines whom the label has applied to, whom it could refer to, and how we might conceive its story. Beginning with a critique of subtle but significant legacies of colonialism inherent within contemporary terms such as "religion" and "politics" as well as "anarchism" and "spirituality," this chapter moves from an overview of literature on "spiritual anarchism" (Sri Aurobindo, Peter Lamborn Wilson, etc.) to discussion of forgotten stories (Krishnamurti, Womanism, MOVE, etc.) and concludes with an eye toward future studies of "spiritual anarchist" praxis (Auroville, Alcoholics Anonymous, etc.).

\section{Introduction}

Despite more than a century of usage and an apparent increase ${ }^{\mathrm{I}}$ in people who espouse some sort of blend between presumably "spiritual" and "anarchist" perspectives, the term "spiritual anarchism"

I In my search for discussions (rather than mere mentions) of "spiritual anarchism," I found more examples in the last ten years than in the last Ioo years combined (see Charts $\mathrm{I}-3$ ). However, through a casual online Ngram search of phrase frequency in English literature, I noticed that the early I930s seemed to have ten times as much frequency of the phrase as today (perhaps due in part to the founding of the Catholic Worker movement or Sri Aurobindo's publications).

How to cite this book chapter:

Fiscella, A. 2020. From Benign Anarchy to Divine Anarchy: A Critical Review of "Spiritual Anarchism". In: Christoyannopoulos, A. and Adams, M. S. (eds.) Essays in Anarchism and Religion: Volume III. Pp. 255-326. Stockholm: Stockholm University Press. DOI: https://doi.org/Io.I6993/ bbb.h. License: CC-BY 
remains relatively obscure and understudied. Scholarship remains limited in at least three senses. First, while various writers have employed the term "spiritual anarchism" (often as if it had a self-evident meaning), no one seems to have ever attempted to chart the terrain-much less examine the term, its usage, or its possible usefulness. Second, those who mention "spiritual anarchism" typically emphasize texts, individual writers, and ideas rather than activism, practitioners, and collective praxis. Third, many groups and figures who might seem directly related to the topic of "spiritual anarchism" do not appear to have received much (or any) attention. In particular, we find a general tendency to downplay or overlook the roles of two cultures that have often overlapped with and provided inspiration for "spiritual anarchists": stateless shamanic ${ }^{2}$ societies and black liberation struggles. In this review, I aim to both provide a broad (albeit non-exhaustive) survey of usages of "spiritual anarchism" as well as critically imagine alternatives that point our gaze in directions where-thus far-the term has not.

In his monumental work, Demanding the Impossible (I992), Peter Marshall traced anarchism back thousands of years to Daoism and Buddhism. ${ }^{3}$ Along the way, he provided the first generic (as opposed to polemical) definition of "spiritual anarchism" (that I know of):

Spiritual anarchists see humans as primarily spiritual beings capable of managing themselves without the curb of external government. Most of them reject man-made laws in favour of a prior obligation to natural law or the law of God; some go even further to insist

2 "Shaman," originally a Siberian reference, remains a contested term (see, for example, Mayer 2008). I apply it here loosely rather than technically and simply point toward the type of decentralized and personal relationships of healers, visionaries, entertainers, and mediators that help regulate the stories that organize social life in stateless societies. Indigenous cultures vary greatly from Lakota to Sami, from Tonga to Hi'aiti'ihi (often called Pirahā). Not all of them share a role that neatly corresponds to that of a shaman (however one defines it) and no single term could adequately describe all such cultures.

3 Many discussions of "spiritual anarchism" mention Zen, Daoism, and/ or quote Lao Tzu. For arguments of Daoism as non-anarchist, see Feldt (20IO); For research on Daoism and anarchism see Rapp (20I2). For anarchism and Zen Buddhism, see Galván-Álvarez (20I7). 
that in a state of grace no law, whether human or divine, is applicable. They generally assume that human impulses are fundamentally good and beneficent. Spiritual anarchism is not linked to any particular creed or sect, but its adherents all reject organized religion and the hierarchical church. ${ }^{4}$

Without dwelling on potential problems in the formulation (e.g., using an undefined "spiritual beings" to define "spiritual anarchists," ambiguity of "state of grace," etc.), tautology (e.g., "capable of managing themselves without the curb of external government" - isn't that plain anarchism?), or assumptions (e.g., "They generally assume..." yet "they" refers to whom?), we can see two key elements inherent in Marshall's definition that may help us understand why people ever use the term at all. First, if "spiritual" implies here a "prior obligation to natural law or the law of God" then it may add a "positive" element to counter anarchism's "negative" opposition-based implication ("an-arch" = against rule). In this sense, obligations-like devotion-may feel empowering because they fill social functions and provide a clear focus for action, routine, ritual, etc. Second, in rejecting "organized religion and the hierarchical church," it seemingly fills the same function as the term "spirituality" (as in "spiritual but not religious") yet, in combination with "anarchism" also provides a nuance to traditional anarchist anti-clerical critiques (implying that "spiritual" approaches need not fall into the same traps as "religious" approaches). Connecting these two elements, we see the possibility of voluntary obligation as well as broad ambiguity: as "creedless" this definition could include atheists and, via "natural law," could include deep ecologists. ${ }^{5}$

4 Marshall 2008: 6. Marshall did not specify whom he included or excluded while explaining "spiritual anarchism" as if it had one uncontested definition.

5 When Naomi Gross sought to identify the Swiss Brethren with "Spiritual Anarchism," she cited the part of Marshall's definition that bolstered her argument. The entire quote follows: "Spiritual Anarchists see humans as primarily spiritual beings capable of managing themselves without ... external government.... [They] reject man-made law in favour of ... the law of God" (2013: I 8). 
In American Gurus (2014), Arthur Versluis, without mentioning Marshall, offered a more narrow but similarly "self-evident" definition:

The term 'spiritual anarchism' ...is a much more extreme form of what we saw more than a century earlier in Transcendentalism, itself an individualistic sport from Protestantism. Here, religious individualism is taken perhaps as far as one could take it. ...Spiritual anarchism, as we will see in other instances as well, is fundamentally different from political anarchism...Typically, spiritual anarchism emphasizes the moment, and a limited space and time within which liberty can be realized. In Zenarchy, Thornley extols the virtues of 'simply knowing that freedom is everywhere for those who dance through life, rather than crawl, walk, or run.' For 'what Zen has most to offer Anarchism is freedom here and now.'

Here we see an emphasis on "freedom" and "liberty" without any reference to obligations. In contrast to Marshall, however, Versluis made it quite clear whom he thought of as the prototype for "spiritual anarchism": Peter Lamborn Wilson aka Hakim Bey whom Versluis felt "brings together, more than any other figure, the many and varied aspects of spiritual anarchism, embodying them as no one else does." 7

Clearly, the proposed definitions of "spiritual anarchism" by Marshall and Versluis clashed yet I could find very little related debate. A few have rejected the term and/or that which it purportedly represented. The controversial book on the European development and global spread of anarcho-syndicalism, Black Flame (2009), dismissed "spiritual anarchism" (e.g., Tolstoy) outright because it "[is] not part of the anarchist tradition .... and arises from a misunderstanding of anarchism. ... There is only one anarchist tradition, and it is rooted in the work of Bakunin and the Alliance." ${ }^{8}$ Christian anarchist scholar André de Raaij (2009) vehemently rejected the term "spiritual anarchism" to describe people like Gustav Landauer or Jacques Ellul because it "reflects current fashions and quests" possibly making "these anarchists

\footnotetext{
${ }^{6}$ Versluis 20I4: I 23, I 28.

7 Ibid: I46.

8 Schmidt and van der Walt 2009: 7 I.
} 
being sold to the millions ... because it tastes of the idiocies of consumer society." 9

A few have argued about clashes between varieties of "spiritual anarchism." In the early I 900 , Sri Aurobindo embraced the term but rejected what he saw as the "extreme" versions of "spiritual anarchism" in Tolstoy and Gandhi. ${ }^{\text {}}{ }^{\circ}$ National anarchist activist Jay Cypher (20I4) not only embraced the term "spiritual anarchism" but described two subcategories "Spiritually Based Anarchism" (in which people create a community based on "shared spirituality and sustained by common bonds and experiences") and "Anarchism as Spiritual Practice" (in which members of a "tribe" do not necessarily share the same "spiritual beliefs" and where "creating an intentional community is a spiritual act in and of itself"). Commenting on this online video presentation, commenter "J. Harris" rejected the entire presentation on grounds that anything associated with "National Anarchism" did not qualify as "spiritual anarchism" because it descended from Julius Evola and "spiritual racism/fascism" and "real spiritual anarchism" rejects "hierarchy and tradition."

These squabbles may seem petty but, in regard to any term that gradually comes into use, they matter. They show the parameters of a term's embryotic development. As Alexandre Christoyannopoulos and Matthew Adams (2018) wrote in the previous volume: "How one defines key terms does, after all, determine what one analyses (and what not), and generally reveals one's assumptions and preferences (implicit or explicit) about

9 Raaij 2009.

Io Varma I990: 300.

II Emphasis added. See comments to Cypher (20I4). National anarchists combine nationalism and anarchism and typically meet strong opposition from antifascists as did Cypher's National Anarchist Tribal AllianceNew York (NATA-NY). Despite Cypher's denial of racism, the broader National Anarchist Movement (NAM) apparently expelled NATA after a dispute about, among other things, whom one should stigmatize: Jews or Muslims. See Troy Southgate, "Important Message," National Anarchist Movement homepage, 26 September 2016, http://www.national-anarchist.net/2016/og/important-message.html; For an anti-racist analysis of national anarchists, see Sunshine (2008). 
what is being discussed." ${ }^{22}$ As scholars do not agree on how to define key terms such as "spirituality," "religion," "anarchism," "state," "justice," or "violence," the conjoining of "spiritual” and "anarchism" into "spiritual anarchism" both amplifies its ambiguity and the difficulty in uncovering implicit assumptions. ${ }^{13}$

With such a wide range of potential meaning, I shall restrict this discussion exclusively to "spiritual anarchism" as a term and, thereafter, critiques and ideas related to that. I shall ignore extensive material on "religious anarchism," I4 "mystical anarchism," " 5 and even work that essentially discusses much of the same material that "spiritual anarchism" has referred to (i.e. work on the following topics and overlaps with many of the themes, concerns, and figures that one finds associated with "spiritual anarchism": stateless societies, ${ }^{16}$ syncretistic struggle, ${ }^{17}$ Swedenborgian syndicalists, ${ }^{18}$

I2 Christoyannopoulos and Adams 2018: I.

I3 I place quote marks around words such as "spiritual," "religion," and "spiritual anarchism" to remind readers that these terms remain ideological, contested, and tentative categories.

I4 In contrast to Marshall's definition of "spiritual anarchism”, "religious anarchism" tends to refer to those who identify with an age-old organized (typically Abrahamic) tradition and/or who adhere to a particular creed such as Christian anarchists (Christoyannopoulos 20II; Foster I997), Muslim anarchists (Crone 2000; Karamustafa 2006; Jean-Veneuse 2009; Kazmi 20I4), Jewish anarchists (Shapira 20I3; Magid 20I7), or anarchist discussion of "religion" (Kennedy 2005; CrimethInc. 2013).

I5 This includes a variety of "mystical anarchisms," including millenarians of the Middle Ages (Cohn I970), certain Russian Symbolists (Rosenthal I977), a later Russian group in the I920s also calling themselves "mystical anarchists" (Nalimov 200I), or various recent works that have propagated the term such as Critchley (2009) and Ladha (2015). For a "social anarchist" critique of "Mystical and Irrationalist Anarchism," see Bookchin (I995).

16 See Barclay (I982) and MacDonald (2012).

17 See McNicholl (2018).

I8 A seemingly improbable category, Ivan Aguéli (I869-I9I7) advocated Sufism, Swedenborgianism, and syndicalism and Helen Keller (I880I968), a member of the International Workers of the World (IWW), also identified with Swedenborg's “spiritual” teachings (Gauffin I94I; Keller I998). For the record, Catholic priest Thomas Hagerty (also Haggerty) wrote the original preamble for the Industrial Workers of the World (IWW) and theorized about its union structure (See "'Father' Thomas J Haggerty.” IWW homepage. 26 October 20II. https://www.iww.org/ 
prophetic resistance, ${ }^{19}$ decolonizing,${ }^{20}$ psychology and anarchism, ${ }^{2 \mathrm{I}}$ liberation psychology, ${ }^{22}$ anarchy and the sacred, ${ }^{23}$ anarchoperennialism, ${ }^{24}$ biographies of people sometimes labeled "spiritual anarchist, ${ }^{25}$ anarchist theology, ${ }^{26}$ anarchist conflict-resolution, ${ }^{27}$ pagan anarchism, ${ }^{28}$ anarchistic "New Religious Movements," 29 anarchism and Satanism, ${ }^{30}$ anarchist abolitionists, ${ }^{3 \mathrm{I}}$ sub-scenes of punk such as taqwacore ${ }^{32}$ or straight edge, ${ }^{33}$ drop-out and psychedelic culture, ${ }^{34}$ utopian/anarchist/mystical communes, ${ }^{35}$ anarchist/ mystical social order, ${ }^{36}$ or any number of antinomian groups such as Thee Temple ov Psychick Youth (TOPY), ${ }^{37}$ Movement of the Free

history/biography/FatherHaggerty and "Father Thomas J. Haggerty's Wheel.” IWW homepage. https://www.iww.org/about/official/wheel ).

19 See McKanan (20II).

20 See Forbes (2008).

21 See Fox (20II), Heckert (20I3), and Lees and Cleminson (201 5 ).

22 See Martín-Baró (I994) and Moane (2003).

23 See Watson (1998) and Kursions (2005).

${ }_{24}$ Closely associated in modern times with Ivan Aguéli, René Guénon, Ananda Coomaraswamy, Julius Evola and others, perennialist philosophy centers on belief in common eternal and esoteric truths underlying all world traditions. For anarcho-perennialism see Cudenec (2013).

${ }^{25}$ For Angelic Troublemakers, a biographical study of Henry David Thoreau, Dorothy Day, and Bayard Rustin, see Wiley (20I4). For a biography of J. Krishnamurti, see Jayakar (I986); for early Sufi Rábi‘a al-Adawiyya al-Qaysiyya of Basra (c. 7I3-80I), see Upton (I988).

26 See Mazura (2017) and Knowles (2002).

27 See Auerbach (1983).

${ }^{28}$ See Starhawk (I998) and Thompson (2016).

29 E.g., the Earth People in Trinidad (Littlewood 2006).

30 For Satanism and anarchism, see Faxneld (20I2).

31 See Perry (1995).

32 See Fiscella (20I2) and McDowell (20I7).

33 See Stewart (2017).

34 See Goffman and Joy (2004).

35 In particular, one prominent anarcho-vegetarian commune in the Swiss Alps named Monte Verità hosted visitors such as Rudolf Steiner and J. Krishnamurti (Green I986) and Tenko Nishida founded the longstanding service-oriented anarcho-commune Ittoen (also Itto-en) in I904 (Nishida I983); For a broad study of anarchist and mystical communes, see Veysey (I973).

${ }^{36}$ See Amster (2003) for overview on social control in anarchist communities, including the Rainbow Family of Living Light and indigenous societies.

37 See Keenan (2003). 
Spirit,,$^{38}$ or the Bāuls). ${ }^{39}$ Finally, in order to avoid attributing the term to people who do not use it, I also excluded discussions that combine anarchism with Daoism, Zen, and "spirituality" but do not use the terms "spiritual anarchism/spiritual anarchist" ${ }_{4}$

While this may sound like an extremely narrow terrain remaining, we might better picture that which "spiritual anarchism" has referred to by contrasting individualist and communal-collectivist variants. Taking one small step beyond the most individualist variants of "spiritual anarchism" which tend to emphasize autonomy, personal issues (drug use, sexuality, asceticism, etc.), magick, ${ }^{4 \mathrm{I}}$ and/ or mind expansion, we might find someone like punk vocalist GG Allin (1956-1993) who said (shortly before dying of a heroin overdose): "I believe that everybody's the ruler of their own temple. If you don't believe that you're Jesus Christ or God or Satan, you're selling yourself short. You can't put any person before number one. Number one is you." ${ }^{42}$ As per Versluis ("religious individualism [taken] as far as one could take it"), this resonates both with the slogan, "Nothing is true-Everything is permitted" popularized William Burroughs as well as Peter Lamborn Wilson/Bey's conception of anarcho-monarchism and the "Imamof-one's-own-being." ${ }_{43}$ Burroughs notably shot and killed his wife, Joan Vollmer, presumably by accident, and Wilson/Bey used his idea of "self-rule" to both imply a "personal ethics which reaches unimaginably higher than any moral code" and advoca-

${ }_{38}$ See Vaneigem (1998).

39 See Bhattacharya (I999).

4० See Clark (I984), Moore (I988), and Murray (I992). Morris characterized Lao Tzu not as a mystic but as an anarchist writing, "he was indeed the first writer to express the libertarian socialist ideal" (I996: 5I).

${ }^{4}$ I Aleister Crowley (I 875-I947) coined the spelling "magick" which characterized an interpretation based on Nietzschean type of will in contrast to "superstitious" connotations. Chaos magicians and TOPY later adopted this spelling.

42 Gangloff I993: I7. Not far from this, one might find the philosophical nihilism of "spiritual terrorist," U. G. Krishnamurti (see, for example, “U. G. Krishnamurti” https://people.well.com/user/jct/ ).

43 Wilson I993a: 65, 74; Following on the heels of Nietzsche's declaration "God is dead," Crowley wrote, "Each one of us is the One God" (Crowley I975: 4). For a Crowley-Discordian-Bey "genealogy," see Greer (2013). 
te adult sexual activity with pre-pubertal children. ${ }^{44}$ As Michael Muhammad Knight put it, Wilson crafted "a child molester's liberation theology" and published it "for an audience of potential offenders." Helms (2004) surmised that Wilson/Bey's most famous work Temporary Autonomous Zones aka TAZ (I985) essentially provided a cover for Wilson/Bey's "paedophile apologies." 45 TAZ also helped inspire various movements including Burning Man. ${ }^{46}$ Therein lies one end of the individualist interpretation of "spiritual anarchism.”

At the other end of the spectrum we see a collectivist approach that tends to emphasize responsibility, connections, community, mediating, healing, solidarity, service, and a sense of oneness with all existence. One step beyond the edge of what people have labeled "spiritual anarchism," we may find something like "natural anarchism" as advocated by pattrice jones (2009): "It's a false kind of freedom that depends on the separation of the individual from the community and its enveloping ecosystem. ...Liberation does not mean freedom from all constraint. Liberation means freedom from unjust or unnatural restraints. ... Thus the ultimate aim of natural anarchism is the restoration of the relationships severed by the state." 47 Without mentioning "spirituality," jones implied natural, justifiable restraints and echoed Marshall's association of "spiritual anarchists" with "obligation to natural law" by declaring: "liberation is connection" looking to animals and nature for inspiration..$^{8}$ On the inner edge of what people have labeled "spiritual anarchist," we find a pagan anarchist, author, and activist such as Starhawk whose vision sounds quite similar to that of jones:

\footnotetext{
44 Wilson I993a: 70.

45 Helms (2004: 3). Versluis discussed Wilson/Bey's "proclivity" for "love of boys" but added that it "is worth recognizing that cultural norms do differ" on this matter (2014: I44).

${ }^{46}$ Harvey 2013.

47 jones 2009: 245-246; Or, as Forbes put it, if a person loses their hand, they still live but if they lose the sun, the plants, or the air, they die: "What is my real body? We are not autonomous, self-sufficient beings as European mythology teaches ...We are rooted just like the trees" (200I: 29I).

48 jones 2009: 245 .
} 
The mysteries are what is wild in us, what cannot be quantified or contained. But the mysteries are also what is most common to us all: blood, breath, heartbeat, the sprouting of seed, the waxing and waning of the moon, the turning of the earth around the sun, birth, growth, death, and renewal. To Witches, the cosmos is the living body of the Goddess, in whose being we all partake, who encompasses us and is immanent within us. ...But power-fromwithin is also akin to something deeper. It arises from our sense of connection, our bonding with other human beings, and with the environment. ... To connect, to build bonds of caring and community, to create structures of support that can nurture us and renew our strength, are powerful acts of resistance. ${ }^{49}$

Starhawk co-founded the pagan Reclaiming Collective as well as women-led anti-militarism network Code Pink, and has led workshops in nonviolent resistance and Earth Activist permaculture courses..$^{\circ}$ As we see, both individualist and communityoriented wings of "spiritual anarchism" tend to identify "self" with the "Divine" yet they seem to mean different things by that assertion (or at least translate them into very different implications and applications). Thus, while people have used the term "spiritual anarchism" to refer to everything in between Allin/Wilson/Bey and jones/Starhawk (as well as beyond that linear spectrum), no one has thus far studied it.

This chapter aims to address and discuss gaps in relevant scholarship as well as provide resources and ideas for new conversations. I do not, however, provide a comprehensive or rigorous study here. Instead, I offer these stories and findings as "conversation starters." To these ends, I purposefully choose breadth over focus veering more toward encyclopedic than theoretical. Deviating from conventional structure, I provide cursory overviews (the resources) interwoven throughout this chapter with cri-

\footnotetext{
49 Starhawk I988: 6, 7 Io, 84.

$5 \circ$ Not without her own challenges, Starhawk faced critique from MaxZine Weinstein (2003) who complained about adulation of the "anarcho-goddess" Starhawk at pagan events and her complicity in that. While believing in "greater forces," Weinstein felt that "spirituality" easily turns into "religion" and "seduces radical anarchists and creates an environment of repackaged religion under the guise of some supposedly liberating spirituality" (2003: 32).
} 
tical reviews (ideas) in dialogue with-not just about-those who advocate some form of "spiritual anarchism." I organize the chapter in the following sequence: introduction to the topic (Section I: Introduction); discussion of conceptual framework and language (Section 2: Concepts and Language); overview of relevant terminology and development (Section 3: Terms and Background); general overview of the literature (Section 4: Material); closer look at selected material with consideration of racial whiteness (Section 5: Critical View: A Race for Anarchy?); presentation of overlooked figures (Section 6: Spirited Away: Forgotten Legacies), and finally a turn toward stories of practice/organization rather than ideas and writing (Section 7: Beyond Words: A Critical View of "Spiritual Anarchist" Praxis). We currently have no field of-or broad conversations-about "spiritual anarchism" but, if we did, what might they look like?

\section{Concepts and language}

Mary Wollstonecraft (I759-I797) insisted that asymmetric power relations ultimately corrupted both sides of a relationship. ${ }^{5 \mathrm{I}}$ The very fact that I can write (in English no less) and publish texts marks my own asymmetrical position of power-while resisting power-in a world where a billion people cannot read and a tiny fraction participate in "expert"-based academia. I value diversity and inclusion yet while varieties of English continue to expand, hundreds of indigenous languages continue to die out or face extinction. In English, we have to work extra hard to see fundamental relationships and interdependence that come more naturally in Native tongues because we have words such as "religion," "philosophy," "politics," "science," and so on that divide the world, divide, knowledge, and divide people-unequally—from one another and the environment upon which we all depend. To help conceptualize underlying complexities, connections, and paradoxes I add a significant caveat to all apparent binaries here: rather than either/or, read both/and (while leaving space for neither/ nor); rather than opposition, read complementarity; rather than

${ }^{{ }^{1}}$ See Wollstonecraft (I792). 
a neat "study" that "proves" a "thesis," read sets of subjective observations and perspectives aimed to challenge assumptions, increase inclusion, and add to existing conversations about radical personal and social transformation. This caveat of admitted "messiness," informed my (imperfect) choice to integrate some Native voices from (in the following order Oglala Lakota, Yankton band/ Standing Rock, Hopi, Yaqui, Klamanth, and Sisseton Wahpeton Oyate) throughout this chapter rather than attempt to select a single one in the section on "Forgotten Legacies." ${ }_{52}$ Native voices collectively share worldviews that fundamentally challenge the conceptual and practical underpinnings and ideologies of English and academic discourse which unconsciously affect all who partake. As Maia Ramnath wrote in Decolonizing Anarchism: "The fact is that every dimension of modernity as we know it was built on colonial history." 53 Reconfiguring one term would entail reconfiguring the broader constellation of ideas in which it found itself embedded. As Timothy Fitzgerald (2007) has argued, the categories of "religion" and "religions", not only form a basis for "the ideology of religious studies," they also play a foundational role in constituting modernity and colonial consciousness: "We are not studying what exists in the world, but by reproducing religion and religions we are tacitly reproducing the whole rhetorical configuration." ${ }^{4}$ In this regard, "anti-religion" anarchists and religious studies scholars alike confirm colonial ideology by using these terms as if they apply universally. Cedric Robinson (1940-2016) went so far as to argue that European anarchists did not actually envision a new society but merely engaged in "rearranging the ideas of that bourgeois society." 55 H. L. T. Quan wrote that, "despite its claim of heresy, anarchism in the West remains faithful and obedient to the ontologies and life-worlds that gave birth to it." ${ }^{6} 6$ Similarly, Russell Means (I939-20I2), of the American Indian Movement (AIM), accused capitalist industry,

${ }_{52}$ To a lesser extent I interspersed mentions of Unitarian Universalists with whom I affiliate.

53 Ramnath 20II: 29.

54 Fitzgerald 2007: 26.

55 Robinson I980: 21 5 .

${ }^{56}$ Quan 20I3: I25. 
as well as "the so-called theories of Marxism and anarchism," of "despiritualizing the universe." 57

Most Native languages did not see a need to conceive of a "religion" or "spirituality" in order to describe their lives. Interestingly, the Chinese word "Dao" translates the "Way" and we hear this term among Native Americans. As told by Vine Deloria, Jr. (I933-2005):

Someone was telling me last night that when the Navajo went to the Parliament of World Religions in Cape Town last year, one of their elders said, "We don't have a religion, but we do have a 'way." That's why you didn't have religious conflict between tribes. You might have fought over everything else-women, horses, or buffalo-but not over religion. Each person, each group, had to do what their tradition told them to do..$^{8}$

While obeying "tradition" may sound overly restrictive, one gets an idea of such "restrictions" from the Hopi as told by Kendrick Fritz: "the Spider Grandmother did give two rules. To all men, not just Hopis. If you look at them, they cover everything. She said, 'Don't go around hurting each other,' and she said, 'Try to understand things.'... You learn to respect everything because you are everything" ${ }^{9}$ Rather than focusing on belief, emphasis has resided on pragmatism. Lee Irwin wrote, Native American spirituality "is not so much about things or actions or quantifiable beliefs, but about the consequences of human decisions, the quality of life, the way things work, how life is valued and enhanced." 60 With such justifiable restraints (recalling jones), Native people did not need "freedom of religion" because they generally did not suppress beliefs. ${ }^{6}$ As Rebecca Tsosie wrote:

...most traditional Native societies did not separate their systems of thought into separate domains of "religion," "philosophy," and "science," although their epistemologies contain all of those functions. To the contrary, many Native societies operate within a

\footnotetext{
57 Means I991: 72-73; Also see Barsh (I988).

${ }^{8}$ Smith 2007: I 2.

59 Heat-Moon I 999: I 87.

60 Irwin I996: 3I0-3II.

6r Also see Lindquist (2014: 87).
} 
holistic understanding of the rules and responsibilities that govern the relations between people and all components of the natural world, whether human or non-human. ${ }^{62}$

By imagining disciplinary categories (which Native people never had) and building institutions of research on those categories (imposed upon Natives through colonial occupation) European "Enlightenment" traditions embedded unconscious ideological commitment into the very fiber of supposedly "neutral" academic language and terminology. Ironically, technical sciences have advanced to the degree that English fails to describe the "reality" that quantum physics reveals. Physicist David Bohm (I980), a friend of J. Krishnamurti's, sought to modify English (a form he called "rheomode") in order to make it more similar to verb-based Native American languages that he saw as better suited to describe quantum mechanics (forces that move rather than "are"). ${ }^{63}$

These perspectives may help explain some of this chapter's idiosyncrasies: (I) As with "religion," I do not assume here that words such as "freedom" or "history" can have non-ideological senses, ${ }^{64}$ (2) I try to speak here of stories and translate "religious belief" or "ideology" as life-organizing stories and "religion" or "politics" as life-organizing practices, and (3) Except when quoting others, I have avoided use of the verb "to be" (which "allows us to play God using the omniscient 'Deity mode' of speech," oversimplifies messy questions of "identity," and ascribes transient reality a static character). ${ }^{65}$ With this conceptual foundation and

Tsosie 20I2: II38.

63 On a related note, see Blackfoot Physics by Peat (2002).

${ }_{64}$ The English word "history" refers to a common language term for "past events," personal life story, as a Eurocentric academic discipline, and as a linear-oriented system of bureaucratic records and documentation using the mythical birth year of Jesus as the center of chronology. For critical views of "history," see Christian (2005) and Fuglestad (2005). The English word "Freedom," refers to a dominant social value with mythic implications (people kill and die for it) yet remains ambiguous, contradictory (always tied to an "unfreedom"), and unnecessary (traditional stateless societies had neither enslavement nor prisons yet no word for "freedom"). For a decolonizing of "freedom," see Fiscella (201 5: I30-276).

${ }_{65}$ Kellogg and Bourland I99I: 42; Bourland refers to English without forms of "to be" as E-Prime. 
appreciation for some limitations and impact of English language bias, we proceed now to terminology.

\section{Terms and background}

This section shall address some fundamental terms related to "spiritual anarchism" beginning with its constituent components and ease toward an overview of early and current uses of the term.

"Anarchism" has elicited a variety of interpretations. This includes reluctant anarchists who oppose government for pragmatic reasons but do not necessarily oppose all government as a matter of principle ${ }^{66}$ and also includes reluctant statists who may regard the state as wrong in principle but do not necessarily oppose government expansion in practical terms. ${ }^{67}$ Finally, it has also included people who simply organize with other people non-hierarchically. ${ }^{68}$

The term "spiritual" has a similarly wide range. Jeremy Carrette and Richard King (2005) traced it from the Latin spiritus (breath of life) to the individualization of the term which ostensibly began with Ignatius Loyola (founder of the Jesuits) in the I 500 s and, in particular, Madame Guyon in the I600s. In the late I 800 s and early I900s, writers, speakers, and activists such as Swami

${ }^{66}$ See, for example, Patricia Crone's (2000) discussion of "reluctant anarchists" such as the Najdiyya and certain Mutazilite ascetics within early Islam. Though they preferred to have a righteous caliphate, circumstances led them to advocate anarchism.

${ }^{67}$ See, for example, Kate Soper's interview with Noam Chomsky who has both advocated anarchism and supported expansion of the federal state or Kropotkin and other anarchists's "reluctant statism" when they supported war against Germany in I9I 6 and received critique from Errico Malatesta who lambasted them as "pro-government anarchists" (Soper I998; Malatesta I977: 248).

${ }^{68}$ Similarly, Barclay distinguished between anarchy ("the condition in which a society is stateless," i.e., traditional indigenous societies) and anarchism ("the socio-political theory developed largely in nineteenth-century Europe which reject all forms of domination") (2002: 105). Broad understandings of anarchism include Mohammed Bamyeh's view of anarchy as the "de facto practice of everyday life" and David Graeber's suggestion of "endless examples of viable anarchism... from a klezmer band to the international postal service" (Bamyeh 20I0: 6I; Graeber 2004: 40). 
Vivekananda, D. T. Suzuki, and Helena Blavatsky (co-founder of the Theosophical Society in I 875) popularized Anglophone interest in Eastern mysticism and the practice of "spiritualism" (communication with the dead) similarly spread during this period.

Descendants of enslaved Africans (like Natives) had European conceptions of "spiritual" diversity forced upon them:

Thrust into the bowels of New World terrorism, her inferior status caused her at times to abort her old life-affirming notions of self and spirituality, and to adopt debilitating ones. She was now subjugated to the European's wants, desires, and ways of life. His puritan mindset, proslavery rhetoric, anti-African ideology, biblical text, and colonial laws served to deaden her precolonial sense of selfhood and seal her subjugation. ${ }^{69}$

With Muslims, Christians, and Animists forced to live together through enslavement, "spirituality" for African Americans morphed into an interfaith practice "that collectively sustained and empowered them in times of crisis. ...It reconnected them to God, the spirit world, land, nature, and each other." 70

During the I 800 s, "spiritual" developed a noun form as African Americans "learned the Christian language of their oppressor(s), reinterpreted and subverted that language, and creatively communicated that subversion in song." ${ }^{7 \mathrm{~T}}$ This could entail blending archetypes from previous traditions with new ones. By "envisioning God and Christ as tricksters and usurpers," African Americans made "a way out of no way" and "used their religious and spiritual convictions to subvert White, racist, and patriarchal hegemony; ...agitate for social justice; and maintain a sense of community." 72 For many people, "spirituality" relates to anything from choir to cooking, from gardening to resistance.

By the I970s, the term "spiritual" could appear without any association of a "spirit world" such as in the second Humanist Manifesto of I973 which stated: "The cultivation of moral devotion and creative imagination is an expression of genuine 'spiri-

\footnotetext{
${ }^{69}$ Harrison 2009: 54.

70 Ibid: 208-209.

${ }^{71}$ Ibid: 200.

${ }^{2}$ Mattis and Jagers 200I: 523.
} 
tual' experience and aspiration." ${ }^{33}$ The term "spirituality" today often connotes what "spiritual anarchism" implied too years ago except, of course, framed in positive terms: "The goal is not to defer to higher authority, but to have the courage to become one's own authority." ${ }^{74}$ This appears relevant because, in the United States alone, an increasing number of people (already I 7 million by 20I2) identify as "spiritual but not religious" (a term popularized by AA and Twelve-Step programs). 75

The first instances that I could find of any variant of "spiritual anarchism" appeared in newspaper articles in the late 1800 s and early I900s. These mentions of "spiritual anarchism" implied or denoted things as varied as atheism, ${ }^{76}$ pacifism, ${ }^{77}$ Theosophy,,$^{78} \mathrm{ab}-$ sence of moral direction, ${ }^{79}$ lawless libertinism, ${ }^{80}$ rejection of biblical authority, ${ }^{8 \mathrm{I}}$ and the dismal state of London cultural life in the I920s. ${ }^{82}$ It often bore a negative connotation as in Mysticism (I9II) where Evelyn Underhill insisted that the "view which regards the mystic as a spiritual anarchist receives little support from history; which shows us, again and again, the great mystics

73 Gina Allen et al. Humanist Manifesto II, I973. https://americanhumanist.org/what-is-humanism/manifesto2/

74 Heelas and Woodhead 2005: 4.

75 Pew Research Center's Religion \& Public Life Project, “'Nones' on the Rise," 9 October 20I 2. http://www.pewforum.org/20I2/Io/og/nones-onthe-rise/ Accessed 27 October 20I4.

${ }^{76}$ A letter to the editor reads: "atheism is anarchism, in the spiritual realm" in the Blue-Grass Blade, Springer I908: I 5 .

77 Krishnamurti I944: I.

${ }^{78}$ A "Dr. Coues" stated that members of the Theosophical Society "are to the spiritual world ... what the Chicago anarchists are to the political world... They are the spiritual anarchists ...If they were numerous enough they would create disorder and confusion, and play sad pranks in society" (Evening Star I 889: I I).

79 According to the British Medical Bulletin, "Without this loving despotism of the parents, the child turns towards spiritual anarchism, becoming a law unto himself, and missing the two primary 'goods' of human life-control of self and consideration of others" (I947: 249).

8० Weltin I956: 382.

8г A "Reverend Omer" stated: "In the divine government, if every citizen were allowed to erect his own standard of duty, we would soon run into a state of spiritual anarchy" (St. Louis Republic I902: IO).

82 Banks I930: 38 . 
as faithful sons of the great religions." ${ }_{3}$ The first instance that I have found of a public advocate for some form of "spiritual anarchism" appeared in the semi-autobiographical novel El Árbol de la Ciencia (I9I I) by Pío Baroja (I 872-I956) where the main character "was inclined to a spiritual anarchism, based on kindness and piety, with no practical solution." ${ }_{4}$ The earliest instance I found of "spiritual anarchist" to describe someone positively appeared in I9I4 where Voltairine de Cleyre (I866-I9I2) posthumously used the term to describe Ralph Waldo Emerson (г 803-1 882). ${ }^{85}$

Around the same period, Sri Aurobindo Ghose (also Ghosh, I $872-$ I950) created perhaps the first explicit and specific articulation of "spiritual anarchism" as an ideology. ${ }^{86}$ Aurobindo wrote "the perfectly spiritualised society will be one in which, as is dreamed by the spiritual anarchist, all men will be deeply free, and it will be so because the preliminary condition will have been satisfied." ${ }^{87}$ Using "Nature" as a guideline, Aurobindo felt that humanity ascended through "spiritual" stages corresponding to individualism/democracy, then socialism, and finally anarchism. ${ }^{88}$ He saw both revolutionary and state force as necessary until the final stage when reason would rule. Probably with Tolstoy and Gandhi in mind, he critiqued "impossible self-abnegation" and "asceticism" which impoverished life and ignored the "many real and valuable gains" of "civilization." 89 Yet, as Vishwanath Varma (I976) observed, Aurobindo did not emphasize "spiritual anarchism" but rather saw it as a byproduct of a "spiritualized society." 90

\footnotetext{
$8_{3}$ Underhill 2002: 95-96.

${ }^{84}$ I9II: 55 (translation my own); Baroja had described himself as "a liberal radical, an individualist and an anarchist" and an enemy of first "Church" and then "State" in that order (Baroja I920: 219).

85 She wrote, "None who are familiar with the thought of Emerson can fail to recognize that it is spiritual Anarchism" (de Cleyre I972: I45).

${ }^{86}$ Aurobindo published his ideas related to this as early as I9 I5-I9I 8 in a series of articles later printed as books in The Ideal of Human Unity (I919) and The Human Cycle (1949).

87 Aurobindo I997: 259.

88 Ibid: 193 .

89 Ibid: 2 I9.

90 Varma I976: 300-304.
} 
W. E. B. Du Bois (1868-I963) figures as an early promoter of some form of "spiritual anarchism" through his use of similar terms as early as the I920s. Like Aurobindo, he saw concentrated power as a necessary stage before ultimately attaining "divine Anarchy" and this bothered him. ${ }^{9 \mathrm{I}}$ Yet, the anarchic goal, however distant, remained important and intimate: "Anarchy of the Spirit alone is the true Freedom." ${ }_{92}^{2}$ Yet in contrast to those who saw inner change as a precursor to social change, Du Bois saw the reverse and maintained that "individual equality and the free soul is impossible" without first establishing an essentially socialist society that guarantees "equality of opportunity." ${ }^{33}$ In David Haekwon Kim's (2004) summary of Du Bois's position: "there can be no spiritual freedom or anarchy without political freedom or anarchy." 94 Despite seeming to differ from Aurobindo in his emphasis on external change as a prerequisite for internal change, their views seem similar. Du Bois, however, did not develop the theme, nor did he have—as Aurobindo did-a woman like Mirra Alfassa (founder of Auroville) who would put those ideas into practice.

Within anarchist contexts, "spiritual anarchism" and "anarchist spirituality" seem to have necessarily implied a rejection of the state. Yet whatever type of "spiritual anarchist," they all seem to reject the authority of church and state in determining beliefs or behavior. Beyond that, they often espouse some sort of sanctification of "self" (defined individually or collectively), a general reverence for nature, conceptions of existential oneness, external social change as intertwined with internal personal change, and an emphasis on immediate experience and/or behavior and a critique of language limitations. In other words, contemporary use of "spiritual anarchism" does, however ambiguously, seem to refer to a certain terrain of ideas and practices wherein people typically view change as both "internal" and "external" and/or identify the self with the divine. If, then, "spiritual anarchism" serves as a useful term in some sense we can examine how some

\footnotetext{
${ }_{91}$ Du Bois [I928] I995: 283.

${ }_{92}$ Du Bois cited in Kim (2004: 69).

93 Kim 2004: 67-69.

94 Ibid: 68. For a development of Du Bois' thought, especially in regard to his limitations on gender, see Griffin (2000).
} 
have used it, how they have not used it, and imagine how we could use it.

\section{Material}

This section shall provide a broad overview of various instances in which the term has appeared in order to capture a bird's eye view of how people have treated the term. The first list includes all people whom I found designated "spiritual anarchist" by someone other than themselves. The second list includes every piece I could find that specifically addressed the topic of "spiritual anarchism" in one way or another. After presenting material in this section, we have a better grasp of what people have already said in order to make preliminary assessments about patterns (if any) and also to discuss what patterns did not appear.

Concerning people whom observers have described as "spiritual anarchist," I found the following: ${ }^{95}$ Lao Tzu, ${ }^{96}$ Leo Tolstoy, ${ }^{97}$ Henry David Thoreau, ${ }^{98}$ William Godwin, ${ }^{99}$ William Blake, ${ }^{\text {1о0 }}$

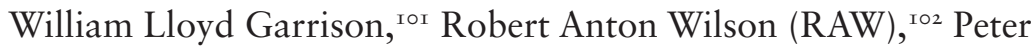
Lamborn Wilson (PLW), ${ }^{103}$ William Burroughs, ${ }^{\text {104 Ralph Waldo }}$ Emerson, ${ }^{105}$ Walt Whitman, ${ }^{106}$ Toshihiko Izutsu, ${ }^{107}$ Max Stirner, ${ }^{108}$

\footnotetext{
95 List compiled primarily through Internet and database searches.

${ }^{6}$ Fox 200I: 19-20.

7 Cannon 20I4.

$9^{8}$ Canby I929: 789 .

99 Ibid.

roo Wilson 2002. Marshall wrote that Blake (I757-I 827) saw humans as interdependent with nature and "went on to reject all moral rules and manmade laws" (Marshall I944: 22). Marshall described him as "visionary anarchist" yet clearly sees Blake as both "spiritual" and "anarchist" (confirmed via correspondence with author I6 February 20I9).

ror Boitani I979: 2 I 8 .

102 Versluis 2014: I36.

103 Ibid: I40.

I04 Ibid: IO4.

105 Žižka-Marušiaková 2012.

${ }_{106}$ Mitchell 20I 5; Sarracino I974: I 5.

107 Ueno 2016.

ro8 Henderson I9I8: 4 .
} 
Friedrich Nietzsche, ${ }^{\text {109 }}$ Henrik Ibsen, ${ }^{\text {Iro }}$ Alan Clements, ${ }^{\text {II }}$ Remy de Gourmont, ${ }^{\mathrm{II2}}$ Pío Baroja, ${ }^{\mathrm{II} 3}$ Abiezer Coppe, ${ }^{\mathrm{II} 4}$ Jacob Frank, ${ }^{\mathrm{II}}$ Henry Corbin, ${ }^{116}$ Henry Miller, ${ }^{117}$ Henry Wright, ${ }^{118}$ Henry "Harry" Hay, ${ }^{119}$ Ivan Illich, ${ }^{120}$ Robert Ingersoll, ${ }^{121}$ Gustav Landauer, ${ }^{122}$ Charlie Chaplin, ${ }^{\mathrm{I} 23}$ Martin Buber, ${ }^{124}$ Mattias Gardell, ${ }^{\mathrm{1} 25}$ Gary Snyder, ${ }^{126}$ John Scotus Eriugena, ${ }^{127}$ Oliver Cromwell, ${ }^{128}$ Shakespeare, ${ }^{129}$ Aleksandr "A. A." Meier, ${ }^{130}$ Nikolai Berdyaev, ${ }^{131}$ Rudolf Steiner, ${ }^{132}$ Jiddu Krishnamurti, ${ }^{133}$ Keshub Chandra Sen, ${ }^{134}$

\footnotetext{
ro9 Goodway 20II: I 57; Iliopoulos 2014: I 2.

I Ibid.

III Pignataro 2003: 20.

I12 Ibid.

${ }^{113}$ Gleaves I97I.

${ }^{114}$ Levy I995: I4I.

II Peter Lamborn Wilson described the neo-Sabbatean Jacob Frank in Poland as "spiritual anarchist" in Akers et al (20I2).

${ }^{116}$ Ben Chasny cited in Riley (2017).

II7 Sarracino I974.

${ }_{118}$ Whyte 20I2: 83.

Ir9 Hay co-founded Radical Faeries. Wilson 2002.

${ }^{120}$ Ibid.

I21 Voorsanger I9I3: 249.

${ }^{122}$ Newman 20IO: I I. Landauer's name often appears in these contexts. For more on his life and work, see Hoppen (2017), Landauer (20I0), and Maurer (I97I).

${ }_{123}$ Zein 20I6: 6-7.

${ }^{124}$ Magid 2017: 58.

${ }^{125}$ Höjer 2007.

${ }^{126}$ Mazura 2017: 34; Ueno (2016: I 53) claimed that Snyder had used the term "spiritual anarchism" in his essay "Buddhist Anarchism" (I96I). I cannot however find evidence of that in any version that I have seen. For more on Snyder's approach to anarchism and spirituality, see Taylor (2005).

127 Eagleton 2010: 25.

${ }^{128}$ Harrison 1908: I49.

I29 Beadle 201 5: 47.

I30 Iliopoulos 20I4: 73 .

${ }^{131}$ Ibid.

${ }^{132}$ Barnes 2005: I7; Also see Preparata (2006).

${ }^{133}$ Gopal I995: 96.

134 Rambachan I994: 27.
} 
Swami Nirmalananda, ${ }^{\mathrm{I} 35}$ Sri Aurobindo, ${ }^{\mathrm{I} 36}$ Osho, ${ }^{\mathrm{I} 37}$ Mohandas Gandhi, ${ }^{138}$ and, three of the few women associated with the term, Starhawk (Miriam Simos), ${ }^{139}$ author Anaiis Nin, ${ }^{140}$ and the British suffragette Dora Marsden. ${ }^{\text {I4I }}$ On a few occasions, authors have described "Hindus" ${ }^{42}$ or "shamans" ${ }^{43}$ in general as "spiritual anarchists." Others have attributed the label to movements such as early Christians, ${ }^{144}$ Anabaptists in general, ${ }^{145}$ Tantra, ${ }^{146}$ Swiss Brethren in particular, ${ }^{\mathrm{I} 47}$ New Age circles, ${ }^{\mathrm{I} 48}$ certain Russian Symbolists, ${ }^{149}$ American Discordians, ${ }^{150}$ and Dadaism. ${ }^{\text {I5 } 1}$

The following charts organize all of the essays, articles, books, lectures, ${ }^{\mathrm{I} 2}$ and blogs that I could find that have explicitly discussed "spiritual anarchism" or "anarcho-spirituality." In order to retain a semblance of focus, I have restricted this list to those

${ }_{135}$ Martin I999.

${ }^{136}$ Chakraborty 1997.

137 Marshall 2010: 530, 746 citing Stewart Edwards, "Spiritual Anarchism," Bulletin of Anarchist Research 2 I July I990: 26. (I have not yet acquired the original source that Marshall cited).

${ }^{13} 8$ Badrinath 2016: 42; Also, see Stallings-Ward comparing Gandhi and Durruti (20II).

139 Amster 201 2: 4 .

I40 Fitch I993: 200.

${ }^{141}$ Clarke I996: 50.

${ }^{142}$ "The Hindu has been a spiritual anarchist, his faith being intensely personal and individualistic" (Mohammada 2007: 79); Also, see Khalfaoui 2009: 85. Sri Aurobindo referred to India's Golden Age as one of “spiritual anarchism" (Ghosh 20II: 45).

${ }^{143}$ Lindquist 2004: 87 .

${ }^{144}$ Jenson and Wilhite 20IO: 8 I.

145 Walker 2013: 57.

146 Dowman I985: 3 .

${ }^{147}$ Gross 2013.

${ }^{148}$ Cuda 2017: 82-83; Citing Bamyeh's definition of anarchism, Cuda wrote: "New spirituality groups can be categorized as forms of anarchism" that "are organized outside of traditional religion, 'voluntarily through various institutions, groups and informal networks, which form a theater of nonstate oriented methods of collaboration [and] mutual aid"” (2017: 93).

${ }^{149}$ Hellman 20I 8: 20. Also see Rosenthal (I977).

I50 Greer 2013: I83.

I5I Fernée 20I4: 28.

${ }^{152}$ I have included recorded public lectures but not online videos/podcasts sans audience. I made one exception with Herve from Los Angeles who identified as homeless. 
that included a variant of "spiritual anarchism" (alt. "anarchist spirituality," "anarcho-spirituality," etc.) in the heading of their presentation or at least use the phrase repeatedly in their talk or text. The more that a presenter performed research, spoke descriptively, tried to present more than one perspective, and provided the listener/reader with sources (footnotes, bibliography, etc.), the more likely I would categorize their work as formal (Chart I). The less they did, the more likely I would categorize it as polemical (Chart 3). As a spectrum, I placed those with a blended approach in the middle (Chart 2).

In the first list (above the three charts) of 46 individuals labeled "spiritual anarchist," we see skewed ethnic representation through an abundance of white male writers (including four Henrys and six Williams/William's sons aka Wilsons), eight Asian names appeared (six of those from India), and no indigenous peoples, Central or

Chart 1. Formal presentations of "spiritual anarchism."

\begin{tabular}{|c|c|c|c|c|}
\hline $\begin{array}{l}\text { Author/ } \\
\text { Speaker }\end{array}$ & Year & Title & $\begin{array}{l}\text { Format/ } \\
\text { Length }\end{array}$ & $\begin{array}{c}\text { Central references } \\
\text { or concerns }\end{array}$ \\
\hline $\begin{array}{l}\text { I.I } \\
\text { Vishwanath } \\
\text { Prasad } \\
\text { Varma }\end{array}$ & I960 & $\begin{array}{l}\text { Spiritual } \\
\text { Anarchism: } \\
\text { Tolstoy, } \\
\text { Gandhi and } \\
\text { Aurobindo }\end{array}$ & $\begin{array}{l}\text { Book } \\
\text { chapter } \\
\text { subheading/ } \\
5 \text { pages }\end{array}$ & $\begin{array}{l}\text { Aurobindo's } \\
\text { pro-technology } \\
\text { and anti-ascetic } \\
\text { "spiritual anar- } \\
\text { chism" versus } \\
\text { the "spiritual } \\
\text { anarchism" of } \\
\text { Tolstoy and } \\
\text { Gandhi }\end{array}$ \\
\hline $\begin{array}{l}\text { I.2 Edwin } \\
\text { Gleaves }\end{array}$ & I97 I & $\begin{array}{l}\text { Hemingway } \\
\text { and Baroja: } \\
\text { Studies in } \\
\text { Spiritual } \\
\text { Anarchism. }\end{array}$ & $\begin{array}{l}\text { Article/ } \\
\text { I } 3 \text { pages }\end{array}$ & $\begin{array}{l}\text { Pío Baroja, } \\
\text { non-activist } \\
\text { anarchism }\end{array}$ \\
\hline $\begin{array}{l}\text { I.3 Carmen } \\
\text { Sarracino }\end{array}$ & I974 & $\begin{array}{l}\text { Henry } \\
\text { Miller, } \\
\text { Spiritual } \\
\text { Anarchist. }\end{array}$ & $\begin{array}{l}\text { Ph.D. } \\
\text { dissertation/ } \\
\text { I I9 pages }\end{array}$ & $\begin{array}{l}\text { Henry Miller, } \\
\text { Zen, Thoreau }\end{array}$ \\
\hline
\end{tabular}


Chart 1. (Continued)

\begin{tabular}{|c|c|c|c|c|}
\hline $\begin{array}{l}\text { Author/ } \\
\text { Speaker }\end{array}$ & Year & Title & $\begin{array}{l}\text { Format/ } \\
\text { Length }\end{array}$ & $\begin{array}{l}\text { Central references } \\
\text { or concerns }\end{array}$ \\
\hline $\begin{array}{l}\text { I.4 Peter } \\
\text { Marshall }\end{array}$ & I992 & $\begin{array}{l}\text { Demanding } \\
\text { the } \\
\text { Impossible: } \\
\text { A History of } \\
\text { Anarchism }\end{array}$ & $\begin{array}{l}\text { Book/8 I } 8 \\
\text { pages }^{\text {I53 }}\end{array}$ & $\begin{array}{l}\text { Daoism, Zen, } \\
\text { Blake, Osho, } \\
\text { Aurobindo, } \\
\text { Gandhi, Vinoba } \\
\text { Bhave }\end{array}$ \\
\hline $\begin{array}{l}\text { I.5 Jana } \\
\text { Žižka- } \\
\text { Marušiaková }\end{array}$ & 2012 & $\begin{array}{l}\text { Spiritual } \\
\text { Anarchy in } \\
\text { Emerson }\end{array}$ & $\begin{array}{l}\text { Masters } \\
\text { thesis/ } \\
68 \text { pages }\end{array}$ & $\begin{array}{l}\text { Emerson, } \\
\text { Daoism, } \\
\text { Zen, Stoics, } \\
\text { Transcen- } \\
\text { dentalists }\end{array}$ \\
\hline $\begin{array}{l}\text { I.6 Arthur } \\
\text { Versluis }\end{array}$ & $20 \mathrm{I} 4$ & $\begin{array}{l}\text { Dogmas, } \\
\text { Catmas, } \\
\text { and } \\
\text { Spiritual } \\
\text { Anarchism }\end{array}$ & $\begin{array}{l}\text { Book chap- } \\
\text { ter/8 pages }\end{array}$ & $\begin{array}{l}\text { Discordians, } \\
\text { Burroughs, } \\
\text { RAW, Thornley, } \\
\text { Benares, Snyder, } \\
\text { Beatniks, magic, } \\
\text { marijuana, Zen }\end{array}$ \\
\hline $\begin{array}{l}\text { I.7 Arthur } \\
\text { Versluis }\end{array}$ & $20 \mathrm{I} 4$ & $\begin{array}{l}\text { Spiritual } \\
\text { Anarchy: } \\
\text { Tantra and } \\
\text { Islamic } \\
\text { Heterodoxy }\end{array}$ & $\begin{array}{l}\text { Book chap- } \\
\text { ter/8 pages }\end{array}$ & $\begin{array}{l}\text { PLW/Bey, } \\
\text { tantra, TAZ }\end{array}$ \\
\hline $\begin{array}{l}\text { I. } 8 \text { Alexei } \\
\text { Anisin }\end{array}$ & 2019 & $\begin{array}{l}\text { Spiritual } \\
\text { anarchism }\end{array}$ & $\begin{array}{l}\text { Subheading } \\
\text { in article/ } \\
3 \text { pages }\end{array}$ & $\begin{array}{l}\text { Nonviolence, } \\
\text { Ahimsa, } \\
\text { Tolstoy, } \\
\text { Berdyaev, } \\
\text { Dorothy Day, } \\
\text { Chris Crass, } \\
\text { Gandhi, } \\
\text { anarchist } \\
\text { spiritual } \\
\text { transformation }\end{array}$ \\
\hline
\end{tabular}

${ }^{153}$ Less than a page of his deals explicitly with the term "spiritual anarchism" yet Marshall views many of the topics covered throughout the book (Daoism, Zen, Blake, Osho, etc.) as falling under into the category. 


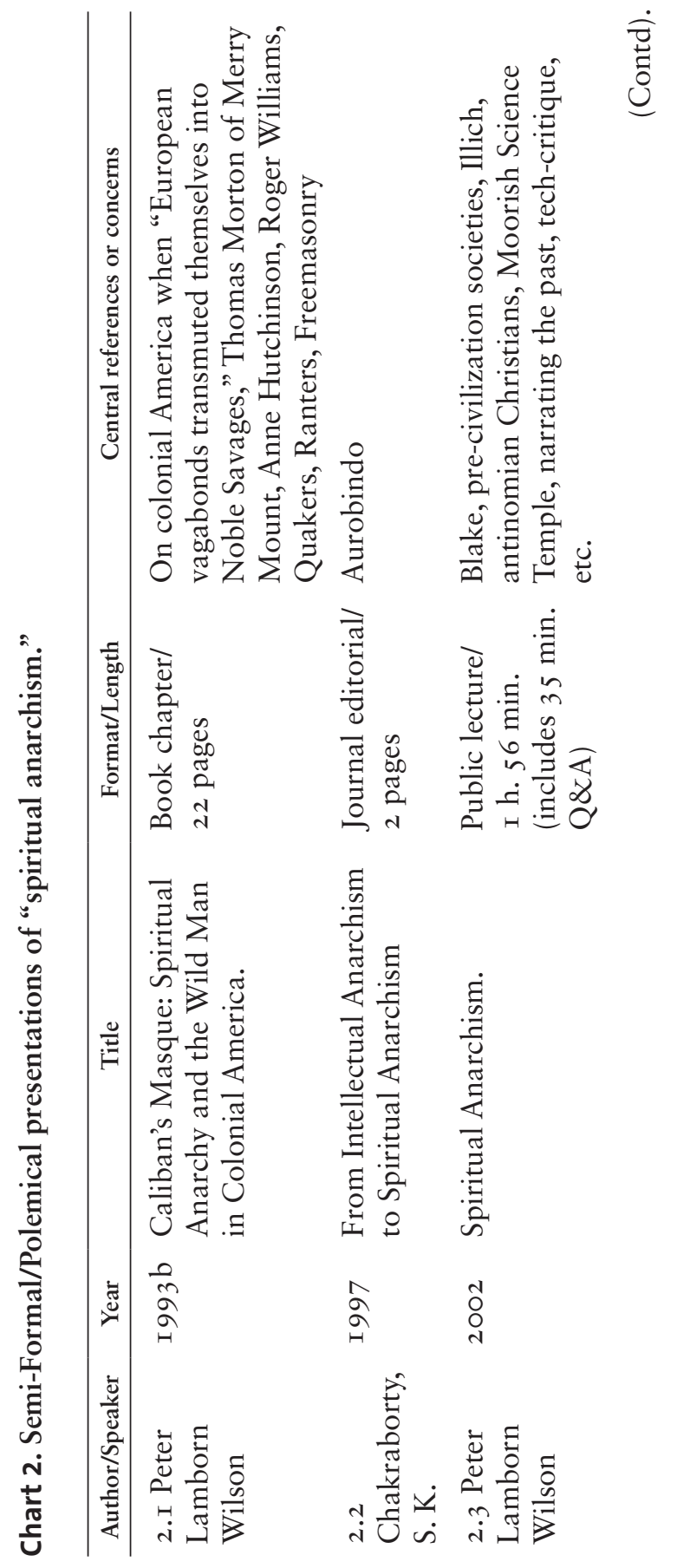




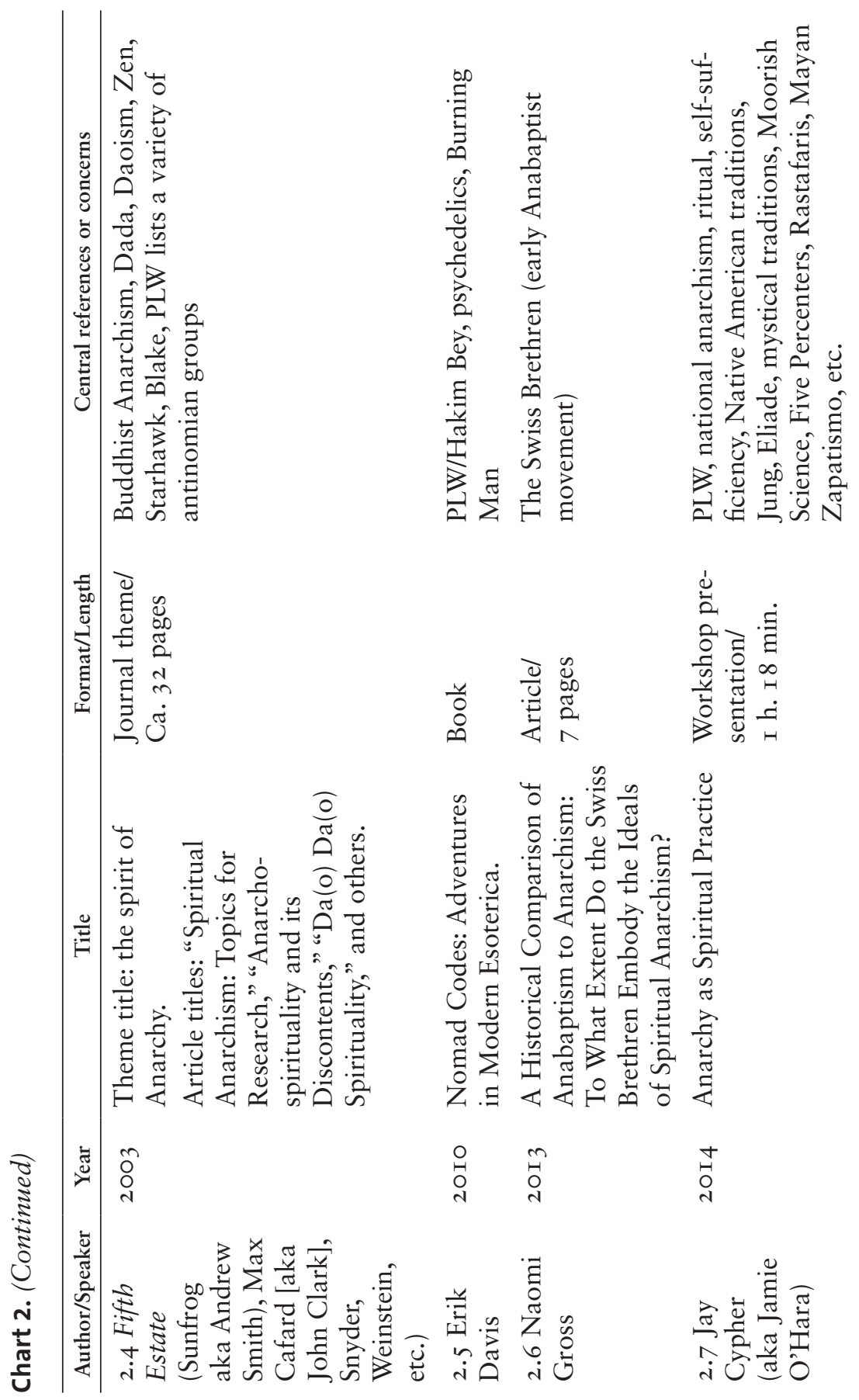




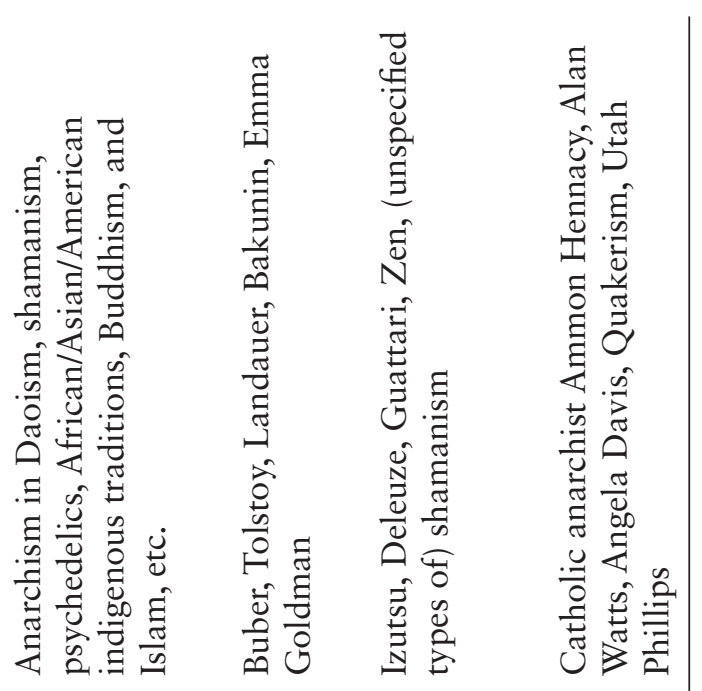

离当敌总

劳

을

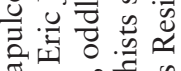

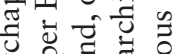

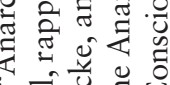

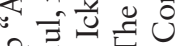

ชิ ซ들

!

콩

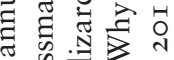

䓃

त

: $\approx$ की

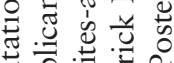

节总式

के 峁客

$\ddot{z} \approx \dot{a}$

ส

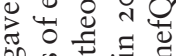

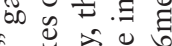

ह을 仓ै

워료.

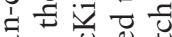

๘ రٓ⿱艹

ธั Чั

兽苛苛

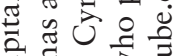

컨

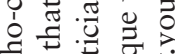

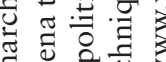

छ

\% 휸

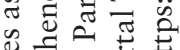

迄

멍

टृ

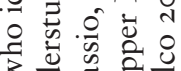

उ

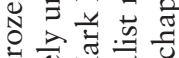

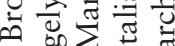

$\infty \stackrel{\infty}{\Xi} \cdot \vec{\Xi}$

드의

ते

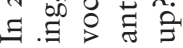




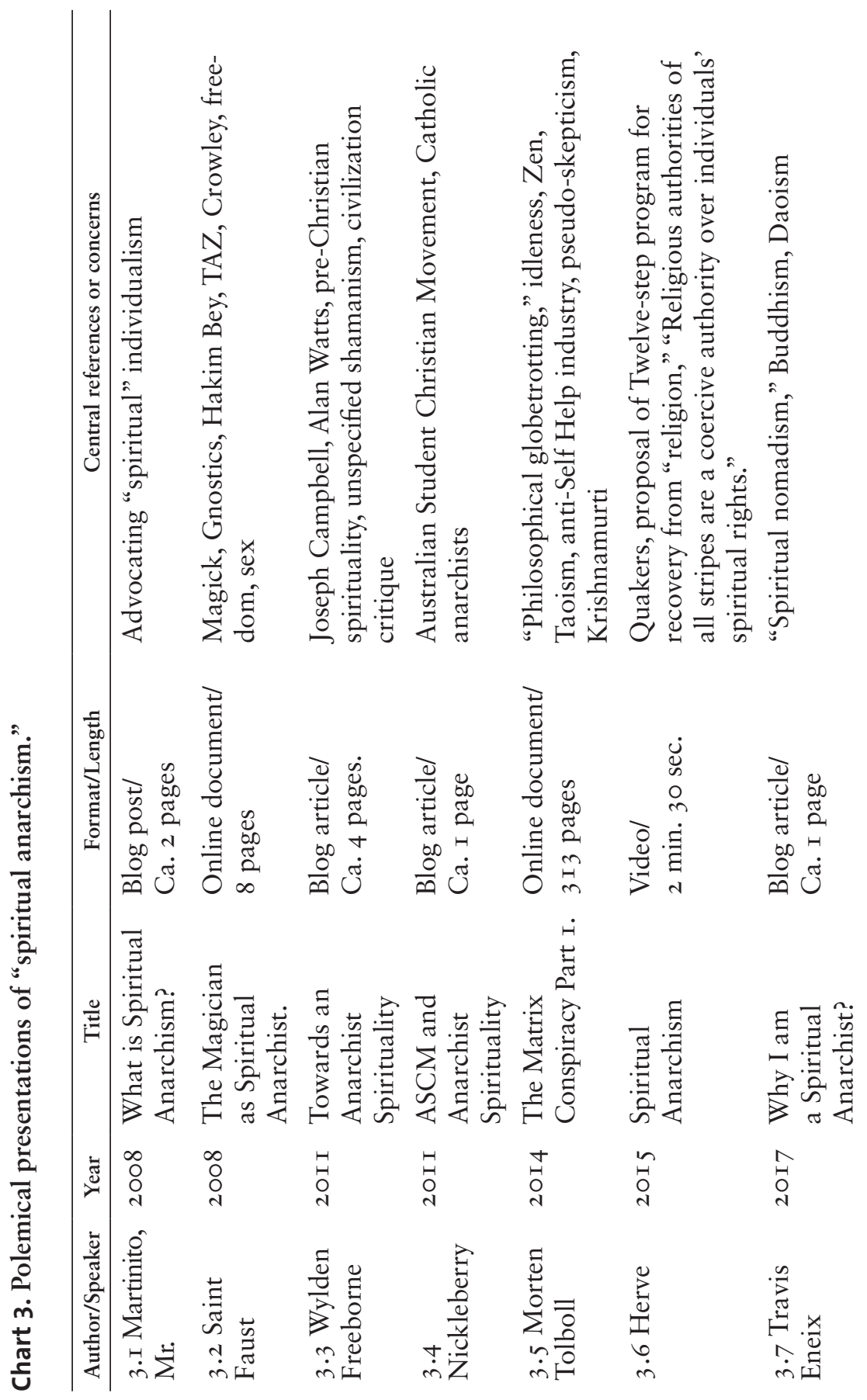




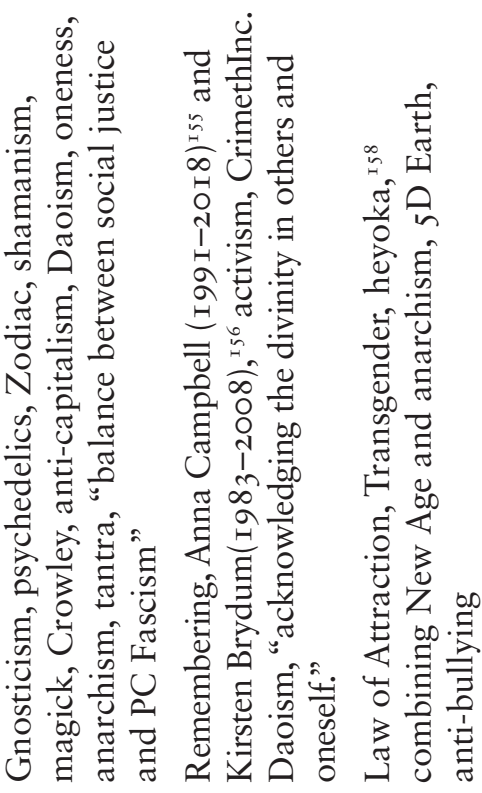

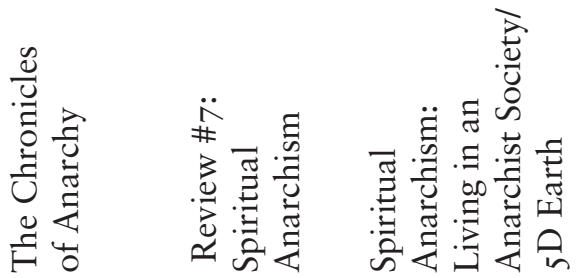

نं

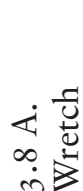

$\stackrel{9}{0}$
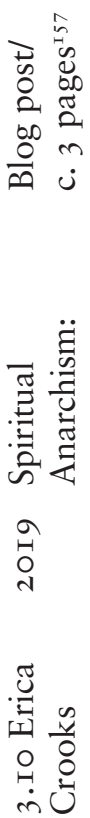

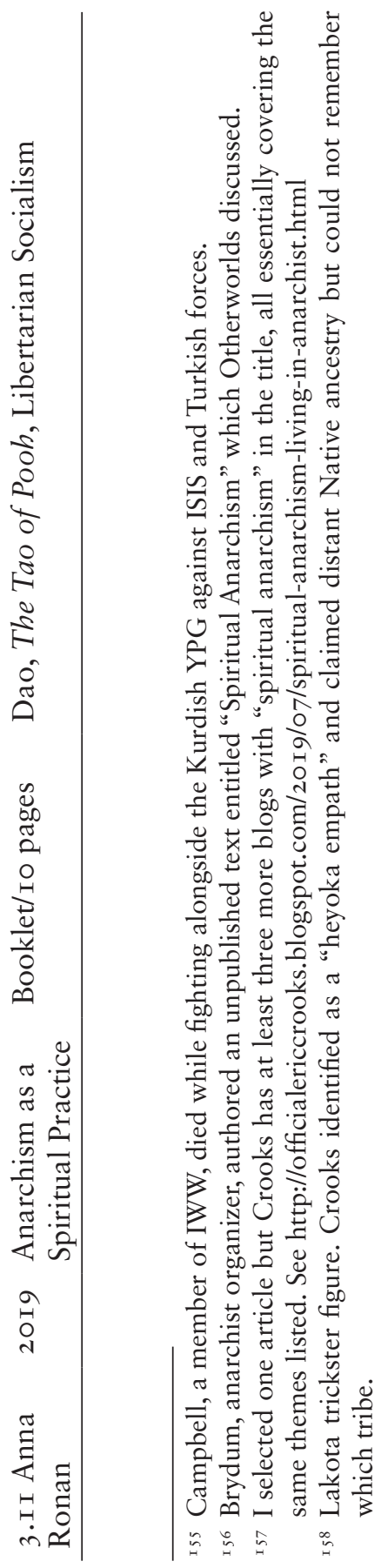

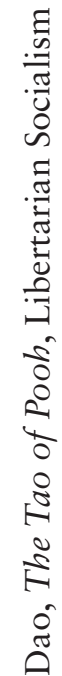

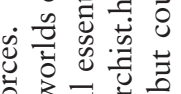
늉 产

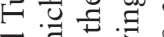
类 ผ $\tilde{\Xi}$ है 큰원

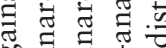
我云盯 苛 플 कै की $\exists$ च्ञ

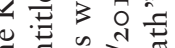
म 눙워

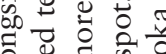
त क bo를 을

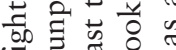
豞 궁 क

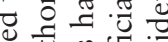
층 능응 \& Ч

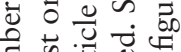

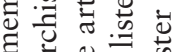
$\approx$ च

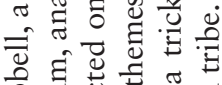

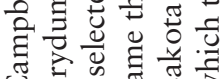
占点点紧 
South Americans, Middle Easterners, Africans, or anyone from the African diaspora. ${ }^{\mathrm{I} 59}$ We see a skewed gender representation with three of the 46 as white women (no women of color). Similarly, in regard to movements, several movements labeled "spiritual anarchist" seemed white-dominant (Dadaism, Anabaptism, and Symbolism), two originated in India, and only in one instance, shamanism, did the term apply to an indigenous tradition.

Although most of the names have acquired renown through their writing rather than activism, in my subjective and open-toquestion view, one might see at least half of the forty-six as engaging in activism or organizing work of some kind, yet only fifteen of thirty-five white males seem inclined in this direction, all six of the Indian males, and two of the three white females engaged in extensive activism. ${ }^{160}$ Also, note that many of the people labeled "spiritual anarchists" did not reject the state on principle (Nin, Cromwell, Aurobindo, Ingersoll, etc.) indicating that the term has sometimes implied broad definitions of "anarchism."

In the second list (Charts $\mathrm{I}-3$ ), of 30 presentations, we find no ethnographic or qualitative studies of "spiritual anarchist" practice. Yet two (I.8 and 2.6) seemed to clearly focus on group practice more than individual writers and their ideas: Gross (2.6) looked at Swiss Brethren practices while Anisin's study on nonviolent activism concluded: "No spiritually committed anarchists have been observed to engage in violent dissent or ... advocating violent actions." ${ }^{6 \mathrm{rI}}$ In my highly subjective assessment,

${ }^{159}$ To clarify, I see race as a social construction (superstition) that powerfully influences social life and I drew these assessments based on popular racial norms to expose the racial dynamics that tend to grant greater attention to people seen as "white men."

160 While tentative and subjective, I categorized the following as engaged in notable activism or organizational work, founding organizations, campaign work, civil disobedience, etc: Garrison, RAW, PLW, Coppe, Frank, Wright, Hay, Illich, Ingersoll, Landauer, Chaplin, Buber, Gardell, Cromwell, Steiner, Sen, Nirmalananda, Aurobindo, Osho, Krishnamurti, Gandhi, Starhawk, and Marsden.

16I Anisin 20I9: 39I; Ambiguities, however, remain. Discussions of Aurobindo (I.I and 2.2) may focus on ideas but Aurobindo's aim toward practice ultimately manifested in the creation of Auroville. Weinstein's (2.4) one-page piece focused personal experiences of group practice, PLW/Bey (2.I, 2.3, and 2.4) and, building on his work, Cypher (2.7), 
eight of them seemed to lean in a communal/collectivist direction and/or emphasize some form of activism, social practice, and/or organization, ${ }^{162}$ twelve seemed to lean toward individualism and/ or emphasized writers, ideas, theory, and/or cognitive transformation, ${ }^{163}$ and thirteen seemed to fit neither category comfortably. ${ }^{164}$ Here, too, we can see an overrepresentation of whites as authors/ presenters, three from Asia (two from India), and none from any Native or African background or perspective. We also see a form of segregation in that mostly Indian writers addressed Aurobindo and the other group of largely (or wholly) white writers generally ignored him and his work. ${ }^{165}$ No presentation in Chart I gave any attention to either Krishnamurti, Native Americans, or African/African diaspora-based groups as "spiritual anarchists." In the next charts, two quoted Krishnamurti (3.5 and 3.8). ${ }^{\text {166 }}$ Shamanism and Native Americans also garner some (not extensive) attention in Charts 2 and 3 , in least eight instances ${ }^{167}$ and we found a slight increase of attention to Africans/African diaspora with discussion of Moorish Science Temple (2.3 and 2.7 $)^{168}$ and

discussed a wide variety of group practices in cursory sketches making them more difficult to categorize here in regard to practice.

${ }_{162}$ See I.8, 2.I, 2.4, 2.5, 2.6, 2.7, 3.9, and 3.I I.

I63 See I.2, I.3, I.5, I.6, I.7, 2.8, 2.9, 2.I0, 3.I, 3.6, 3.7, and 3.8 .

${ }^{164}$ See I.I, I.4, 2.I , 2.2 2. 2.3, 2.4, 2.5, 2.II, 3.2, 3.3, 3.4, 3.5, and 3.I I.

165 Marshall gave Aurobindo a paragraph (I992: 529). Versluis mentioned Aurobindo twice in his book but not in relation to "spiritual anarchism" and likewise for Tolboll. I have seen only one anarchist studies scholar, Brian Morris, give any notable attention to Aurobindo (I996: I08-III).

${ }^{166}$ Inspired by Krishnamurti's assertion that "Truth is a pathless land" and his conception of "aloneness," Tolboll devoted an entire section of his book to Krishnamurti (2014: I9-26); Wretch quoted Krishnamurti as stating "it is no measure of health to be well adjusted to a profoundly sick society" (n.d.: 7I).

${ }_{167} 2 . \mathrm{I}, 2.10,2.3,2.7,2.8,3.3,3.8$, and 3.IO.

${ }^{168}$ The Moorish Science Temple (MST) appears repeatedly in Wilson/Bey's work. In the early I900s Noble Drew Ali (I886-I929) re-named/reclaimed African Americans as "Moors" and re-interpreted Jesus to mean "justice." He founded the Moorish Science Temple which spread its teachings through a new scripture: The Circle Seven Koran (no relation to the Quran) in the years immediately prior to the founding of the Nation of Islam by W. D. Fard. In I986 Wilson revived a defunct white beatnik "branch" of Moorish Science named the Moorish Orthodox Church 
brief mentions of "Bwiti people of Africa" and their use of the plant Iboga plant (2.8). ${ }^{169}$

Only Cypher (2.7) discussed Fiver Percenters ${ }^{170}$ and Rastafaris, noting that the former broke down "ISLAM" as "I Self Lord And Master," and "ALLAH" as "Arm Leg Leg Arm Head" (references to the self as God). ${ }^{171}$ In regard to Rastas, Cypher acknowledged them as a decentralized group fighting an oppressive state (Babylon) with degrees of self-sufficiency and they engage in "reclaiming and redefining language based on their spiritual views." 172

Finally, Waldo Noesta (2.II) quoted black liberation scholar Angela Davis's revision of the Serenity Prayer: "I am no longer accepting the things I cannot change. I'm changing the things I cannot accept." ${ }^{173}$

As with the first list, most-but not all—of the presentations advocated a rejection of the state as well as church authority.

(see Knight 20I2: 20-23; 87-92). The MST shared commonalities with the Ahmadiyya, Rosicrucians, Theosophical currents, Freemasons such as the Ancient Egyptian Arabic Order Nobles Mystic Shrine (Black Shriners), and, in name at least, the Moorish Zionist Temple founded in I 899. For more on MST, see Curtis (2009), Nance (2002). For black Freemasonry (a major influence on the MST and later the Nation of Islam) see Sesay (2013).

${ }^{169}$ Broze and Vibes (201 5: 48) referred (in passing) to the Bwiti tradition in Gabon in regard to the psychotropic Iboga plant. So did Wretch who also mentioned the Somali xeer system of conflict resolution (n.d.: 425, 85).

${ }_{170}$ Also known as the Nation of Gods and Earths (NGE).

${ }^{171}$ Promoting an egalitarian and antiauthoritarian interpretation of Islam via Nation of Islam (NOI) teachings, Five Percenters similarly reject the idea of a "mystery God" in the sky. They re-named Harlem "Mecca" and Brooklyn "Medina," they avoid pork, and yet, unlike the NOI, they adamantly reject the label of "Muslims"-in favor of "Gods" (Knight 2007). Five Percenters have developed a complex interpretational system called the Supreme Alphabet and Supreme Mathematics, which they use to build on tradition with new interpretations, essentially co-creating doctrine in participatory democratic gatherings reminiscent of the Viraśaivas of twelfth century India where men and women would share poetry together in meeting halls and co-create group doctrine (Schouten I99I: 4).

${ }^{172}$ Cypher 20I4. Indeed, the Rasta term "I-and-I" means both "we" and "God." As Edmonds noted, for Rastas the "locus of authority is in each individual" (2003: 7I).

173 Noesta 2019. 
If exclusively white and Asian people have used the term "spiritual anarchist," that may help explain why we have never heard the term "anarchist spiritual" to refer to African American spirituals. Frederick Douglass said he would "bow to no priests either of faith or of unfaith," ${ }^{774}$ yet I have yet to see anyone declare him a "spiritual anarchist." This, in light of a range from Shakespeare to Anaïs Nin and from Cromwell to Ingersoll, begs the question as to who does not qualify. Dynamics of whiteness and structural racism seem to play a role in perception of the term but they do not fully explain "spiritual anarchism's" apparent boundaries: I could not find anyone having ever described two well-known white men, Noam Chomsky and William James, as "spiritual anarchist." With the former a prominent anarchist who has advocated "spiritual transformation" ${ }^{775}$ and the latter a forerunner of contemporary "spirituality" who advocated anarchism, ${ }^{176}$ one might think they would qualify. While exploring such questions lies beyond the scope of this chapter, we can take at least take a closer look at how some racial dynamics seem to have related to "spiritual anarchism."

\section{Critical view: a race for anarchy?}

Tensions between people of color and white anarchists have long persisted in various forms. ${ }^{177}$ "Spiritual anarchists" have proven no exception. Adopting ideas from Indigenous peoples, African Americans, or "heretical” Islam-even "respectfully"-does not come without complications. Looking back we can see a long-term pattern of stolen words and distorted tales. Innocent Onyewuenyi argued that, "what we call Greek or Western Philosophy is copied from indigenous African philosophy of the 'Mystery System.' All

\footnotetext{
${ }^{174}$ Aptheker 200I: 77.

${ }_{75}$ Chomsky supported Rosa Luxemburg's call for “spiritual transformation" (Chomsky 2013: 46).

${ }^{176}$ William James wrote in I900: "I am becoming more and more an individualist and anarchist and believer in small systems of things exclusively" (Coon I996: 8I).

177 E.g., Lagalisse (20II) and Hahn (20I4: I 24).
} 
the values of the mystery system were adopted by the Greeks and Ionians who came to Egypt to study." ${ }_{178}$

As white Freemasons took inspiration from Islamic and Middle Eastern cultures, the Founding Fathers drew from Native Americans as they imagined and conceived new forms of governance. Two primary examples shall illustrate some tensions in contexts of "spiritual anarchism": the literary blackface and orientalism of Wilson/Bey and Burroughs. Let's start by looking at two quotes:

[D]ue to self-detrimental mental programs that have been installed in you by your parents, family, society, school, religion, consensus reality, etc. you have been limited and disabled.

- Hakim Bey, Secret of Secrets, 20 I I.

What mysticism really tries to surmount is false consciousness, illusion, Consensus Reality, \& all the failures of self that accompany these ills.

$$
\text { — Hakim Bey, T.A.Z. 1985/2003. }
$$

The two quotes seem to reference a single author and both mention "consensus reality" yet appearances deceive. How? Quite simply: two different people currently write under the name "Hakim Bey." The first Hakim Bey, author of Secret of Secrets, ${ }^{179}$ appears African American, self-identifies as a Moor, and has membership in the Moorish Science Temple. The second Hakim Bey (PLW) appears European American, self-identifies as an anarchist, and, after working for the government of the Shah of Iran, returned to his native New York and revived the Moorish Orthodox Church (a somewhat Discordian-like white beatnik network of Noble Drew Ali enthusiasts). As Knight stated, "people often speak of the 'black Hakim Bey' and the 'white Hakim Bey' as though they're oppositional twins in some cosmic dualism.” ${ }^{80}$ By writing T.A.Z. under that pseudonym, Wilson gave readers the image of a black man precisely because the name evokes the Moorish Science Temple (where members typically adopt the last name "Bey" or

\footnotetext{
${ }^{178}$ Cited in King I999: 29.

${ }_{179}$ Written under the name Moorpheus H. B. (2OI I).

ז80 Knight 201 2: 70.
} 
"El”). By borrowing the color and assumed authenticity of blacks, this male white gained street credibility and performed a symbolic coup by firing the imagination of readers who might otherwise have found an identical text by "Peter Lamborn Wilson" less inspirational. Furthermore, the words, "Hakim" ("wise") and "Bey" ("prince"), have very different implications in relation to race in the United States. When a black man takes a name of prestige, he acts to re-capture a sense of dignity, humanity, and prestige that whites had stolen from him and his ancestors. Whites (especially from the upper middle-class) who call themselves "wise princes" build upon a racial foundation of prestige and skin privilege created through theft, exploitation, and colonialism.

In another example, William Burroughs and Brion Gysin popularized the phrase "Nothing is true-everything is permitted" (hereafter NITEIP) which has appeared in mainstream cultural contexts such as the TV series True Blood and the computer game Assassin's Creed. It seems to offer universal license for any activity. Burroughs attributed the phrase to the last words of the famous head of the Assassins, Hasan-i Sabbah, and, through his fictional writing, Burroughs built up his own mythology around Sabbah. In Wilson's words: “Nothing is true; everything is permitted.' This was the teaching of Hasan-i Sabbah, the first Grand Master of Alamut, called the Old Man of the Mountain.” ${ }^{181}$

Miles (2000), Gieger (2005), and later Knight (2012) falsely described NITEIP as the result of a "cut-up experiment" by Burroughs. ${ }^{182}$ Supposedly Gysin and Burroughs had rearranged or simply taken the words from a chapter heading in Betty Bouthoul's (1936) book on the Assassins and haphazardly connected it to Hasan-i Sabbah's dying words. The story fails on several counts. First, Bouthoul used the exact phrase "Nothing is true; everything is permitted" ("Rien n'est vrai, tout est permis") both as chapter title and in the text claiming that Hasan-i Sabbah spoke it as his dying words. ${ }^{183}$ Burroughs and Gysin simply took the phrase and story directly from Bouthoul without any creati-

\footnotetext{
18г Wilson I988: 56.

${ }_{182}$ "Cut-up" = the cutting up text and rearranging the words. See Geiger (2005: I45-I48) and Knight (20I2: I8).

I83 Bouthoul I936: I96.
} 
ve input. Nietzsche had also used the phrase ("Nichts ist wahr, Alles ist erlaubt") decades earlier yet both he and Bouthoul seem to have taken the phrase from an I 8 8 book in Bouthoul's bibliography by Joseph von Hammer-Purgstall who used variations of the phrase to describe the philosophy of the Assassins but he neither attributed the phrase directly to Hasan-i Sabbah, did not use quote marks, nor cite any source for the phrase. ${ }^{\mathrm{I}}{ }_{4}$ It seems that von Hammer-Purgstall interpreted the Ismailis; Nietzsche popularized this interpretation; Bouthoul embellished it and placed the phrase in Hasan-i Sabbah's dying mouth; Gysin and Burroughs popularized the phrase in the U.S. (and mystified their own behavior with smoky clouds of Eastern exoticism). This mystique served not only to justify raw individualism but also disguise their own relationships to colonialism and racism. ${ }^{\mathrm{I}}{ }^{5}$ The disguise worked so well that biographer Miles could list "all of the hideous personages" of Burroughs, including "Hassani-Sabbah" and "an old Southern nigger-killin' sheriff" without mentioning any racial implications. ${ }^{186}$

By taking the reader through the gradual steps of this narrative construction I hope it clarifies how passive acceptance of "white people's words" combined with orientalist manipulations both objectifies and distorts colonized cultures and-in Wollstonecraft's terms-corrupts both sides of the asymmetrical relationship. From Quakers' problematic and paternalistic relationship with Native Americans ${ }^{187}$ to complex ways in which Freemasons both created interfaith community centers based to some degree on mutual aid and also primarily served white people (including Unitarians and Universalists such as Thomas Starr King, Thaddeus Mason Harris, and Hosea Ballou as well as anarchists such as Mikhail Bakunin and occultist Aleister Crowley),

${ }^{18} 4$ Thanks to Jeff B. Taylor at Vanderbilt University who conducted this research and supplied details through correspondence: “Origins," https:// my.vanderbilt.edu/jefftaylor/publications/origins/

185 For more on Orientalism and how white Occidentals have a long tradition of shaping and distorting images of the East, see Said (I979) and King (1999).

${ }^{186}$ Miles 2000: I 84-I 85 .

I87 Milner I982. 
race has affected social justice struggles. ${ }^{\mathrm{I} 8}$ While the Unitarian Universalist Association (UUA) organizes according to a congregational polity akin to Bakunin's federalism and act as pioneers of social justice, they too have struggled with racism in their membership and institutions. ${ }^{189}$ Even an anarchist such as John Collier helped entrench colonialism when he helped shape the Bureau of Indian Affairs for the U.S. government. ${ }^{190}$ More recently, the anarchic and largely white Rainbow Family of Light, also called Rainbow Nation, came into conflict when they planned to gather 8,000-20,000 people in Black Hills, South Dakota in 2015 and a Lakota group, United Urban Warriors Society, viewing the land as sacred, ardently opposed the plan. Two Lakota activists complained that "the Rainbow Family has no leaders, and no one is really accountable." ${ }^{\text {} 91}$ Michael Muhammad Knight came into conflict with Five Percenters when he accused Lord Jamar of homophobia. Knight ended his identification as a Five Percenter and framed his departure as a result of sexism and homophobia among Five Percenters (both of which he knew of when he joined). He accompanied his farewell essay with a pink and lavender version of the Five Percenter's logo, the Universal Flag, to which a QueenAishah Intelligence responded "looks like you an agent[.] your determined idea was never to learn because if it was you would do just that and stay in your lane[,] not turn around and slander the Nation take the flag and disrespect the people that made it." ${ }^{192}$ Tensions appear even in close relationships. Across

${ }^{188}$ For prominent Unitarians and Universalists as Freemasons, see Sala (2000). For Bakunin as Freemason, see Lagalisse (2018: 297). Crowley additionally admitted working as an agent for the British state (Spence 2000: $36 \mathrm{I}$ ).

ז89 For Bakunin's outline for anarchist federation, see Dolgoff (2002). For racism and the UUA, see Morrison-Reed (20II). For UUs and anarchism, see Dewey (2004). For an anarchist UU approach to challenging racism, see Crass (200I).

190 Hauptman I983.

I9I Briquelet 2015. Ultimately, both sides seemed divided on the question and less than I,500 "Rainbow warriors" showed up with minimal confrontations.

${ }^{192}$ See Knight 2013 plus comments. 
chasms such as racial divides, we can at least begin with acknowledging the violence of silence.

\section{Spirited away: forgotten legacies}

With much focus on individual white writers, focus on people of color and activist groups has fallen by the wayside. While impossible to address all such cases, this section briefly covers J. Krishnamurti, Earth First!, Womanism, MOVE, and indigenous peoples.

Discussions of "spiritual anarchism" in general have largely ignored J. Krishnamurti's tremendous, long-term, and widespread influence. Aside from his literature, videos, and recordings, Krishnamurti's legacy continues on in the schools that he founded. Furthermore, many anarchists and activists over the years have taken his message to heart. In 2005, the journal Green Anarchy published an anonymously written text on Krishnamurti's philosophy (alongside references to Daoism, William Blake, and Dadaism). For the author, one of Krishnamurti's most important contributions entailed his emphasis on challenging authorities in our "internal environment," the presuppositions that unconsciously direct us. After all, "if 'spirituality' is synonymous with self-awareness, then those that don't seek it are all mad as hatters. ... all robots, and sleepwalkers." The author concluded with quotes from Krishnamurti such as:

Friends, why don't you worship a cloud? Why don't you pray to the man who is labouring in the fields, or take delight in shadows cast on tranquil waters? While you are worshipping in an enclosed shrine, Life dances in the street and escapes you. If you do not test your strength by throwing away your crutches, how can you know your integrity, your vitality? ... and enjoy that which creates all things. ${ }^{193}$

The author did not mention (and perhaps did not know) that other anarchists have discussed Krishnamurti's work. Krishnamurti influenced a wide range of people from writers such as Aldous Huxley, Henry Miller, Marshall Rosenberg, Alan Watts, and Timothy Fitzgerald to activists such as the Black Panthers, martial arts le-

${ }^{193}$ Krishnamurti quoted by Green Anarchy (2005: I3). 
gend Bruce Lee, Osho, and the founders of the anarchist commune Beeville in New Zealand. ${ }^{194}$ At one point in time, an anonymous editor surreptitiously cut and pasted his words into an apocryphal text supposedly documenting a debate between W. D. Fard (founder of the Nation of Islam) and Albert Einstein in I933. ${ }^{195}$

As early as I93 I the feminist Maria Lacerda de Moura wrote in Estúdios that Krishnamurti had influenced her. ${ }^{196}$ In I935, Krishnamurti critiqued war, nationalism, and "religion" through seven lectures in São Paolo and Rio de Janeiro and Brazilian anarchist press covered his talks positively. ${ }^{197}$ According to Mendiola, in I936, a Spanish vegetarian named Celestino García avoided "politics" and studied Krishnamurti. He and a friend attempted to evade participation in the Spanish Civil War yet ultimately consented to serve in the Bakunin battalion without bearing arms. ${ }^{198}$ In 1960 the newspaper of the syndicalist AIT/CNT in exile, Solidaridad Obrera published an article by J. Tato Lorenzo, co-founder of the Hermanidad Universal Anarquista, where he discussed Krishnamurti's teaching on ending exploitation and balancing reason and emotion through experimentation: "Find your own path and rise forth.... Belief is the wealth of the ignorant." I99

${ }^{194}$ Black Panther David Hilliard stated, "we lived by some of the Eastern philosophies of Krishnamurti. Vegetarianism was a big thing in our BPP. Our school was vegetarian [and] children were on a vegetarian diet." “The Satya Interview with David Hilliard,” 2004. http://satyamag.com/ apro4/hilliard.html). Bruce Lee created a new martial arts style, Jeet Kune Do, based on Krishnamurti's teaching (O'Regan 2005). Osho's commune Rajneeshpuram named a lake after Krishnamurti (Carter I990: I0). For his influence on Rosenberg, see Rosenberg (2003: 28). Inspired in part by Krishnamurti, members of the Beeville commune (1933-1973) in New Zealand lived a vegetarian and pacifist lifestyle, engaged in direct action (such as the refusal to pay "war taxes"), regularly served time in jail for refusing military service, and once even broke a fellow member out of prison (Sargisson and Sargent 2004: 33-35).

195 Aside from Krishnamurti (I970: I 29), the text also lifted liberally from Sikh and Christian Scientist sources. For a more detailed discussion, see Fiscella (20I 5: 36I-363).

${ }^{196}$ Queluz 20I8.

197 Ibid.

198 Mendiola 201 5: I2. (Thanks Santiago Gorostiza!)

199 Lorenzo I960: I. Translation from Spanish my own. Supposedly anarchists associated with the individualist anarchist journal Iniciales also 
In his I973 work on communes, Laurence Veysey wrote: "Emma Goldman thought it was worth devoting half a page of Mother Earth to a scornful account of Krishnamurti's first arrival in America as the announced Theosophical avatar." ${ }^{200}$ However, Goldman's text appeared in I9I3. Krishnamurti (barely I 8 at the time) did not arrive in the U.S. until I922. Nor did the article mention Krishnamurti's name or seem to know anything about him. It stated: "It is fortunate that this time the Savior of the world is to be a real Yankee. Were he-God forbid-a foreigner, he would in all probability fall into the hands of the Immigration Bureau and be deported, so that the millions of Americans would be robbed of salvation and be doomed to eternal hell-fire." ${ }^{201}$ Later, Road to Freedom, a follow-up journal to Mother Earth, quoted Krishnamurti positively in I930. ${ }^{202}$ In I952 Henry Miller described Krishnamurti thusly:

His career, unique in the history of spiritual leaders, reminds one of the famous Gilgamesh epic. Hailed in his youth as the coming Savior, Krishnamurti renounced the rôle that was prepared for him, spurned all disciples, rejected all mentors and preceptors. He initiated no new faith or dogma, questioned everything, cultivated doubt (especially in moments of exaltation), and, by dint of heroic struggle and perseverance, freed himself of illusion and enchantment, or pride, vanity, and every subtle form of domination over others...."You seek truth," he says again, "as it if were the opposite of what you are."

"Man is his own liberator!" Is this not the ultimate teaching? ... He has often been referred to as "the World Teacher." If any man living merits the title, he does. But to me the important thing about Krishnamurti is that he imposes himself upon us not as a teacher, nor even as a Master, but as a man. ${ }^{203}$

studied Krishnamurti's work yet I do not have documentation to verify this.

${ }^{200}$ Veysey 1973: 45-46. Based on Veysey, Lagalisse repeated this information (2018: 307).

${ }^{201}$ Mother Earth I9I3: 196. Thank you to Candace Falk at the Goldman Papers for digging up this source!

${ }^{202}$ Veysey I973: 49.

${ }^{203}$ Ibid: I 53 , I 59. 
Miller's depiction neatly captured a contradiction behind the allure and drama of Krishnamurti's seemingly egalitarian message: it depended upon the elite status that he rejected. In demolishing that glamorous pedestal he settled for a more modest one but he never lived an adult life without a pedestal.

For others who have spoken a similar message, attention has not come so easily. Especially when they have translated those ideas into action. We find, for example, very similar starting points of Oneness with nature in womanism, Earth First!, and The MOVE Organization who turned these basic premises into a pragmatic call to defend animals and Mother Earth from assault by humans. Alice Walker, inspired by Zen (among other things), wrote:

Womanism is a social change perspective rooted in Black women's and other women of color's everyday experiences and everyday methods of problem solving in everyday spaces extended to the problem of ending all forms of oppression for all people, restoring the balance between people and the environment/nature, and reconciling human life with the spiritual dimension. ${ }^{204}$

A womanist: "Loves the Spirit ...Loves struggle. ...Loves herself. Regardless." "205 Walker, who has expressed support for MOVE, wrote: "Certainly I don't believe there is a God beyond nature. The world is God." ${ }^{206}$ Not only does womanism embrace diverse DIY "spiritualities," it involves an inclusive and broad-based "struggle against oppression based on race, gender, and class." 207

Although given a name recently, one can trace the intersectional essence of womanism much farther back. For example, Frances Ellen Watkins Harper (I825-I9II), an orphan who grew up to write and speak as one of the country's foremost authors and abolitionists. Historian LaRese Hubbard described Harper as "one of the most important figures in African American intellectual history" and a "womanist sani-baat, a Wolof word and Senegalese

204 Phillips 2006: xx. At least one scholar, Jessica Sadr, has noticed that "natural anarchism and ecowomanism share conceptual and practical similarities for addressing ecological degradation and remedying uneven relationships between humans and non-human life" (2013: I8).

205 Walker I983: xii.

206 Ibid: 265 .

207 Vanessa Sheared cited in Razak (2013: 22I). 
concept of 'voice throwing' [meaning] a disruptive and self-affirming insertion of women's voice in spaces and discourses which would exclude or silence them." ${ }^{208}$ Harper called for "[e]arnest, self-sacrificing souls" who would make their mark and not allow "blood stained government" to buy their loyalty. ${ }^{209}$ When living in Philadelphia, she attended both the white First Unitarian Church and the black African Methodist Episcopal Church where she taught Sunday school class. In response to racism in the suffragette movement, she teamed up with Harriet Tubman ${ }^{210}$ and others to found the National Association of Colored Women (NACW) in I 896 (reaching I00,000 members by I924). ${ }^{211}$ With the slogan "Lifting as we Climb," the NACW "built schools, ran orphanages, founded homes for the aged, set up kindergarten programs, and formed agencies in New York and Philadelphia to help female migrants from the South find jobs and affordable housing." 212

According to Nash, Dave Foreman, white co-founder of the generally anarchist eco-activist group Earth First!, "liked to say that 'I'm operating as part of the wilderness defending myself,' and that monkeywrenching was 'self-defense on the part of the Earth." ${ }_{213}$ Another environmental activist described "spirituality" as knowing "what the trees are saying. ...It has [convinced me we are not] separate from each other, and from the rocks, and everything else." ${ }^{214}$ With these perspectives various Earth First! and animal liberation activists have committed acts of sabotage to prevent companies from "developing" land and killing or incarcerating animals. Bron Taylor described tactics of Earth First! and animal liberation activists as including tree spiking, sinking whaling ships, hunt sabotage, and arson attacks against trucks, research laboratories, ski lodges, or meat factories. Often however

\footnotetext{
${ }^{208}$ Hubbard 201 2: 68, 74.

209 Sehulster 20I0: II38.

210 For more on Tubman, whom Monica J. Evans called "that most prominent of outlaw women," see May (20I4); Evans cited in jones (2009: 239).

2ir Now called the National Association of Colored Women's Clubs (NACWC).

212 Rubiner I996.

213 Nash I989: 196.

${ }^{214}$ Taylor 2010: 97.
} 
"self-defense on the part of the Earth" has entailed less confrontational methods. In December I997, a vegan activist named Julia "Butterfly" Hill climbed a giant redwood (dubbed "Luna" by Earth First! activists) in order to save the tree from logging. She spent two years living atop the tree, enduring winter storms and frostbite, yet "drawing strength from the tree" and only coming down "after negotiating an agreement with the logging company that left Luna standing as well as a two-hundred foot buffer of surrounding trees." ${ }^{215}$ She said she could feel the tree crying when the company had cut down trees in the vicinity. Graham Innes buried himself in a road up to his neck in order to hinder a company from cutting down trees. He described how, during this period, he felt an "awareness of a hitherto unknown connectionEarth bonding [when the Earth's] pulse became mine, and the vessel, my body, became the vehicle for her expression." ${ }_{216}$ In 2012 the Earth First! Journal published three pages by and about The MOVE Organization. ${ }^{217}$ Here we could read, for example, Phil Africa writing from prison:

I just wanted to show some appreciation for the work yall do. It does us all good to see people out there with the courage to stand up for what's Right against this rotten system. ...People need to realize that when they take a stand for what's Right it is for Themselves they are fighting for. People must realize that there is Nothing more important than LIFE/NATURE. ... To quote JOHN AFRICA: “THE EARTH IS FOOD, WITHOUT EARTH THE SEED IS DEAD, WITHOUTH THE SEED THE EARTH IS DEAD, WITHOUT FOOD ALL LIFE IS DEAD FOR IT AIN'T THE CABBAGE THAT IS THE FOOD, IT IS THE LIFE IN THE CABBAGE THAT KEEP YOU ALIVE. EARTH IS LIFE, THE CABBAGE IS EARTH, WHEN YOU EAT THE CABBAGE YOU ARE EATIN' THE SOIL JUST A[S] SURELY AS YOU ARE DRINKIN' YOUR BREATH WITH EVERY SWALLOW OF WATER WHEN THIRSTY” ...end quote LONG LIVE JOHN AFRICA! ${ }^{218}$

\footnotetext{
215 Taylor 2010: 94 .

216 Ibid: 95 .

${ }^{217}$ For a comparison of MOVE's significance in legal studies and their relative exclusion from religious studies, see Fiscella (2016).

${ }^{218}$ Africa 2012: I2. Particular spellings and emphasis in original.
} 
John Africa founded the MOVE Organization in Philadelphia in the early I970s. Based on the principle of the absolute unity of life, members lived communally and strove to end all violence (including pollution, racism, prisons, and war). Rejecting trash collection, they put their food scraps on their yard and attracted large numbers of roaches and rats. Defending these "vermin" against pesticide probably made MOVE the first activist group to defend the rights of insects. ${ }^{219}$ After a period of weekly study sessions of the teaching of John Africa, MOVE began protesting zoos, pet stores, and the local Board of Education. Confrontations with police left a MOVE infant dead in I976, a police officer dead in I978, nine MOVE members serving 30-Ioo year sentences, and a I 985 bombing of their home by police which killed eleven people (including five children) and left 250 people homeless. ${ }^{220}$ Survivor of the bombing Ramona Africa has long served as spokesperson for MOVE's continuing activities. Now, MOVE members have raised a generation of urban home-schooled sober youth who express deep concern for animals and nature.

How differently would we think of MOVE and John Africa, a black man, if people would come to believe (correctly or falsely) that his parents who arrived in Philadelphia from Georgia in the early I 800 s had Cherokee background? Would these principles of oneness with life, rejection of technology, and harmony with nature somehow seem more ...natural?

Not only do the values of Krishnamurti, Earth First!, womanism, and MOVE resonate with one another, they resonate too with indigenous peoples who seem to, by and large, match or surpass criteria to which the terms "spiritual" and "anarchist" often seem to apply. Native societies resolved conflicts and crime

${ }^{219}$ Jain ascetics, of course, have avoided killing insects for hundreds of years yet have not, as far as I know, actively defended insects' rights. MOVE and Jains struck a prophetic chord: scientists now assess that corporate pollution, pesticides, and habitat devastation threaten a third of insect species and the entire eco-system of Earth along with them. See technical meta-study at Sánchez-Bayo and Wyckhuys (2019) and popular science overview in The Guardian by Carrington (2019).

220 Boyette and Boyette I989; Two MOVE members, Merle Africa and Phil Africa, have died in prison. The rest of the "MOVE 9" served $40-42$ years in prison before exiting on parole 20I8-2020. 
without formal law or incarceration, ${ }^{221}$ provided integrated and inclusive forms of psychotherapy, ${ }^{222}$ and they typically organized without state, police, homelessness, standing armies, great wealth disparities, and largely in sustainable relationship with sacred environment. ${ }^{223}$ Furthermore, many Native peoples have had more than two genders and/or allowed transition between them. ${ }^{24}$ As seen recently in Standing Rock and other places, many Native Americans/First Nations people continue to challenge corporate and settler state power. ${ }^{25}$

Clearly, more than ample material has existed in excluded contexts for people to have potentially characterized them as "spiritual anarchist."

\section{Beyond words: a critical view of "spiritual anarchist" praxis}

This section imagines what studies of "spiritual anarchism" might look like if they examined actual groups and practices. I selected two institutions, Auroville and Twelve-Step programs/Alcoholics Anonymous because (a) I had a degree of familiarity with them as well as access to research on them, (b) they both constitute early pioneers in "spiritual anarchist" contexts; and (c) they both captured my personal interest as groups that created new lifeorganizing stories and practices designed to heal relationships to self and society. Although I only provide a sketch rather than an actual study, this may hopefully inspire closer examination of these groups and many others.

Mirra Alfassa ( I 878-I973), a disciple of Sri Aurobindo, founded perhaps the largest "spiritual anarchist" commune in the world: Auroville, a "cluster of ecovillages" in southern India with more than I,500 residents stewarding 3,000 acres of land. ${ }^{26}$ Alfassa founded Auroville on February 28, I968 in southern

\footnotetext{
221 E.g., Okulski (2017).

222 E.g., Lindquist (20I4).

223 E.g., Barclay (I982).

224 E.g., Gilden (2006).

225 E.g., Gilio-Whitaker (2019).

226 Mueller I990: I I I.
} 
India. Asked by an interviewer about the type of organization that she hoped to see in Auroville, the Mother answered: "a divine anarchy." 227 Today, members run Auroville as a network of eco-villages consisting of more than 2,000 residents. Their website states that "there are no leaders as such; each person is responsible for the collective becoming of Auroville" and also "The bulk of Auroville's administration is carried out by autonomous and non-hierarchic working groups." 228

Yet, Auroville, as studied by Joukhi (2006) and Namakkal (2012), also exemplifies a group of well-intentioned colonists. The members of Auroville initially viewed their Tamil neighbors with great respect. Yet Aurovilians' respect for the locals also assumed that the Tamil would understand the magnificent project of Auroville as superior to their own existing lifestyle and Tamil traditions. Due to cultural differences and economic disparities, the initial vision of absorbing the local populace into Auroville gave way to a sense of resignation. Instead of joining Aurovilians as equals, the local Tamil worked as servants and provided cheap labor for the Aurovilians who, by and large, did not come from the local region (many came from Europe, the U.S. or northern India) and they did not speak Tamil.

The creation of Auroville, a Western utopia, in India, a site of Western colonial expansion, reproduced colonial institutions, specifically those of race, class, and nation, thus maintaining continuity between the colonial and the postcolonial periods that the architects and visionaries behind Auroville had explicitly hoped to avoid. ${ }^{229}$

In Jukka Jouhki's words: "It seemed as if the Aurovillian ideal of 'unity in diversity' meant unity in Western diversity." ${ }^{30}$ This "anticolonial colonialism" (as Namakkal termed it) stemmed from the structural institutions of the global economy and the classes and peoples that it privileged even if the members of Auroville aimed to abolish that system. As far as I can tell, Aurovilians still struggle

\footnotetext{
227 Anonymous I977: 28.

${ }_{228}$ See www.auroville.org

229 Namakkal 201 2: 62.

230 Jouhki 2006: I 86 .
} 
with the issue even while they have made progress. In addition to outreach programs, they have begun teaching Tamil to children in Auroville schools. ${ }^{23}$ Despite setbacks and difficulties, they have persevered. From their humble beginnings, for example, in a largely barren terrain, they planted approximately 2 million trees in their first 30 years alone. ${ }^{232}$

Today with "inhabitants from about 40 different nations" Auroville consists of "nearly roo communities of varying sizes" and "has nearly two dozen schools, a number of research institutes, cultural centers, a seed bank, forests and sanctuaries, appropriate technology and renewable energy centers, and many commercial units." ${ }_{233}$ Among the features that have contributed to Auroville's success, one resident stated ten "essential ingredients" including "commitment to being willing servitors of the divine (in a philosophical rather than religious sense)," a "sense of humor that usually manifests in bizarre forms of self-criticism," and "a refusal to believe in impossibilities.” ${ }^{234}$

Bill Wilson aka Bill W. (I895-I97I) and Robert Smith aka Dr. Bob (I879-I950) founded Alcoholics Anonymous (AA) in Akron, Ohio in I935 and in I939 published the "Twelve Step program" which millions of people have used to address various types of addictions. ${ }^{235} \mathrm{AA} /$ Twelve Step programs have meetings organized across the world but reject all forms of coercive organization. They lack both membership lists and leaders (rejections made explicit

${ }^{23 \mathrm{r}}$ For more on Auroville, see Minor (I999), van den Akker and Lipp (2004), and Vengopal and Kumari (2010).

232 Mueller I990: II I.

233 Ibid: II 2.

${ }_{234}$ Ibid: II3. Watson (I998: I72-I74) also noted Native use of humor in overcoming dualism.

235 The twelve steps include: admit powerlessness in relation to addiction; believe a "higher power" could help; decide to turn one's life and will over to that higher power; perform moral self-inventory; openly admit wrongdoing; feel ready for "God/higher power" to remove the defects; make such a request; make a list of people wronged and feel prepared to make amends; make amends; continue self-inventory and admit when wrong; use prayer and meditation to ask for direction and strength to follow through; having completed the previous steps, spread the message. See Kurtz (I979) and AAWS (1957). 
in Tradition Nine that guides AA groups). ${ }^{236}$ Participants identify themselves only by their first name (hence, the "anonymous" aspect of AA). Bill W. described AA as a "benign anarchy." ${ }_{237}$ At its core, it functions as a form of decentralized mutual aid for people in need. Mark Andersen, co-founder of the straight edge punk activist collective Positive Force, described Twelve Step programs such as $\mathrm{AA}$ as "a powerful model ... with their use of personal inventories, amends-making, and service." Andersen continued:

In our hierarchical, profit-driven health care system, where doctors can almost assume the role of God, such groups represent a radical alternative. Rotating leaders, no fees involved, the "sick" helping one another, with only the loosest of structures-what more profound refutation of our present system could there be? Even the word "God" is left for each person to define for themselves, or to even reject outright, should another word like 'greater power' seem preferable. In their way, these meetings, autonomous except in matters affecting other Twelve Step groups, seem strikingly like anarchy in action. They begin with an admission of powerlessness over some aspect of life, but only in order to harness a deeper, broader power. The aim of the process is a small but very real liberation, one that can help clear the way for larger transformation. ${ }^{238}$

${ }^{236}$ Tradition Nine of the Twelve Traditions states: “'A.A., as such, ought never be organized; but we may create service boards or committees directly responsible to those they serve.' ... Neither its General Service Conference, its Foundation Board, nor the humblest group committee can issue a single directive to an A.A. member and make it stick, let alone mete out any punishment. ...It is clear now that we ought never to name boards to govern us, but it is equally clear that we shall always need to authorize workers to serve us. ...If nobody does the group's chores, if the area's telephone rings unanswered, if we do not reply to our mail, then A.A. as we know it would stop. ...Tradition Nine ... discloses a society without organization, animated only by the spirit of service-a true fellowship." Thanks to Elena Metcalf for pointing this out to me years ago. For AA and spirituality see Kelly and Greene (20I4) and Westermeyer (2OI4).

237 AAWS I957: 225; Butler (2010) even wrote a book bearing this title. Butler credited AA's decentralized and non-partisan approach with its massive success in establishing itself throughout Ireland.

${ }_{23} 8$ Andersen 2004: I 24. 
In another sense, its pragmatic inclinations and lack of critique of the state and state violence as such, has (unsurprisingly perhaps) led to collaborations with the state. Hence, although ostensibly a purely voluntary enterprise, the state can force prisoners into attending an AA program. ${ }^{239}$ Nonetheless, Twelve Step programs have led to discernable changes in many people's lives. Al Smith (I9I9-20I4), a Native American who had grown up without contact with the Klamath tradition of his parents eventually succumbed to alcoholism but recovered through AA. Therein he began to rekindle his ancestral ties and a relationship with, in his words, "a God that I didn't even understand.” ${ }^{40}$ When employers fired his work colleague for using peyote, he stood up for him and attended a Native American Church ceremony involving peyote. His legal defense of peyote use went all the way to the Supreme Court. Though the case lost, it led to a popular uproar that culminated in a 1993 congressional act to rectify it, the Religious Freedom Restoration Act (RFRA).

Whereas the "benign anarchy" of Twelve-Step programs/AA does not threaten the status quo per se, it can create important spaces for mutual aid, DIY education, self-organization, and healing within nation-state contexts. Whereas the "divine anarchy" of Auroville does not necessarily threaten the status quo either, the acquisition of land, creation of egalitarian organization via (semi-)permanent communal living can enable mini-versions of new egalitarian societies. Figure I illustrates that each of them have their corollaries in other contexts and may potentially combine in an infinite number of constellations.

In Twelve-Step's "benign anarchy," we find an egalitarian approach that empowers its members to cooperate horizontally toward healing themselves and personal relationships. In Auroville's "divine anarchy," the group tends toward both healing and building a new society alongside personal development. Both revealed promise for social transformation as well as, recalling Wollstonecraft's observation about asymmetric power relations, complicity with existing power structures. Both examples seem to

239 Peele, Bufe and Brodsky (2000).
${ }_{240}$ Epps 200I: I9. 


\begin{tabular}{|l|l|l|}
\hline & $\begin{array}{l}\text { Structural type } \\
\text { of “spiritual } \\
\text { anarchism" }\end{array}$ & Possible manifestations \\
\hline $\begin{array}{l}\text { Individual } \\
\text { association }\end{array}$ & Benign anarchy & $\begin{array}{l}\text { Twelve-step programs; } \\
\text { anarchist affinity groups; } \\
\text { co-counseling communities; } \\
\text { study circles }\end{array}$ \\
\hline $\begin{array}{l}\text { Community } \\
\text { organization }\end{array}$ & Divine anarchy & $\begin{array}{l}\text { Egalitarian eco-villages; } \\
\text { leaderless communes; tribal } \\
\text { organization }\end{array}$ \\
\hline $\begin{array}{l}\text { Other areas } \\
\text { (global, natio- } \\
\text { nal, nomadic) }\end{array}$ & Combination & $\begin{array}{l}\text { Bakunin's federative } \\
\text { system; Unitarian Universalist } \\
\text { Association; Eco-village } \\
\text { network; global trade unions; } \\
\text { international DIY networks }\end{array}$ \\
\hline
\end{tabular}

Figure 1. Benign Anarchy and Divine Anarchy.

suggest that whether a "benign anarchy" or a "divine anarchy," all attempts to heal, repair, build, and sustain egalitarian communities today do so in relation to the complexities of power disparities, inequalities, and violence of governments, class, and race.

\section{Conclusions?}

In this chapter, I have addressed a notable gap in research by scanning uses of "spiritual anarchism" and, in particular, noted Marshall's broad definition of "spiritual anarchism" that left space for (unspecified) collective-oriented groups and obligations to "natural law" or "God's Law" in contrast with a definition by Versluis which associated the term very specifically with the individualistic "freedom"-focused white Beatnik writers and Peter Lamborn Wilson/Hakim Bey. Second, I discussed racial dynamics concerning the latter group. Third, I addressed voices largely excluded from "spiritual anarchist" discourse (including Krishnamurti, Earth First!, womanism, MOVE, and indigenous peoples) to provide potential counter-prototypes. Finally, with the examples of Auroville and Twelve-Step programs/AA, I offered a sketch of a praxis-based study of "spiritual anarchism." 
Initially, "spiritual anarchism" caught my attention because it seemed to often point in directions that interested me (i.e., social and eco-justice work, radically revising dominant language and life-organizing stories, challenging patterns of violence inwardly and outwardly, building community, etc.). I don't know that we need a single term for all of that. But, if some people use "spiritual anarchism" to refer to those (and many other) things, it may warrant studying what people do with it and if the term continues to provide a function for thinkers, activists, and organizers as a means of harmonizing personal and social struggles then it may also warrant decolonizing. ${ }^{24 \mathrm{I}}$

In a discussion about the need to include Indigenous perspectives in interspecies thinking, Kim TallBear (2OI I) mentioned her skepticism toward the idea of beginnings. She argued that, along with the word "origin," we "should dump that word 'genesis' from our scientific vocabulary" because such terms obscure the actual dynamics of "different pieces" forming to "make a new kind of whole." Life, as we know it, offers no "discrete beginning," so unless "we are talking about the Big Bang, we probably should not use these terms." ${ }^{42}$

One could perhaps say something similar about the idea of endings. This several thousand-word journey ends where it began: with an awareness of the limitations of words. Which terms should we use when we speak and when we study? This chapter ends with a respect for the unknown and a willingness to listen. What happens if we look closer at the ways people relate to terms like "spirituality" and "anarchism" and what do these relations say about larger societal challenges? What impact does the exclusion of women and people of color from discourse have on the emphasis of individualism and "freedom" versus connection to community and "justice"? This chapter ends with an attempt to shift focus from life-organizing stories toward life-organizing practices in that terrain

${ }^{24 \mathrm{I}} \mathrm{Or}$, if people choose a new term altogether, why not choose a verb (like daoing?-but less awkward-in reference to the Dao) or, in a nod to Russell Means' opposition to colonial despiritualizing of the universe, respiritualizing?

242 TallBear $201 \mathrm{I}$. 
where questions morph into experiments. Perhaps, in scratching the surface, this chapter may spark conversations.

\section{References}

Africa, Phil. "LONG LIVE MAMA NATURE FOREVER!” Earth First! Journal 32, no. 2 (20I2): I 2.

Akers, Tyler et al. "In Conversation with Peter Lamborn Wilson." Brooklyn Rail. 4 October 20 I 2.https://brooklynrail.org/20 I 2/Io/art/ peter-lamborn-wilson-with-tyler-akers-rabia-ashfaque-carina-badalamenti-matthew-farina-jessica-holmes-candy-koh-naomi-lev-david-levi-strauss-sabrina-locks-tara-stickley-erin-sutphin-terrencetrouillot-and-david-willis

Akker, Jos van den and Judith Lipp. "The Power of Human Unity: Renewable Energy in Auroville." Refocus 5, no. 3 (2004): 26-29.

Alcoholics Anonymous World Services (AAWS). Alcoholics Anonymous Comes of Age: A Brief History of A. A. New York: Harper, 1957.

Amster, Randall. "Restoring (Dis)Order: Sanctions, Resolutions, and 'Social Control' in Anarchist Communities." Contemporary Justice Review 6, no. I (2003): 9-24.

Amster, Randall. Anarchism Today. Santa Barbara, CA: Praeger, 20 I 2.

Andersen, Mark. All the Power: Revolution Without Illusion. Chicago: Punk Planet Books, 2004.

Anisin, Alexei. "Violence, Resistance, and Social Transformation in Anarchist Thought and Practice." Journal of Religion \& Spirituality in Social Work: Social Thought 38, no. 4 (2019): 383-400.

Anonymous. The Mother on Auroville. Pondicherry: Madanlal Himatsingka, I977.

Aurobindo, Sri. The Human Cycle; The Ideal of Human Unity; War and Self-Determination. Pondicherry, India: Sri Aurobindo Ashram Press, I997.

Auerbach, Jerold S. Justice Without Law? New York and Oxford: Oxford University Press, I983. 
B., Moorpheus: H. Secret of Secrets: The Revelation of OCCOULIA. MBMDT Publishing, 20I I.

Badrinath, Tulsi (ed.). Chaturvedi Badrinath: Unity of Life and Other Essays. New Delhi: Oxford University Press, 2016.

Bamyeh, Mohammed A. Anarchy as Order: The History and Future of Civic Humanity. Lanham, MD: Rowman \& Littlefield, 20 Iо.

Banks, Paul. Metropolis or The Destiny of Cities. London: The C.W. Daniel Company, I930.

Barclay, Harold. People Without Government: An Anthropology of Anarchism. London: Kahn \& Averill and Cienfuegos Press, I982.

Barclay, Harold. "Islam, Muslim Societies, and Anarchy." Anarchist Studies IO, no. 2(2002): I05-II8.

Barnes, Henry. Into the Heart's Land: A Century of Rudolf Steiner's Work in North America. Great Barrington, MA: SteinerBooks, 2005.

Baroja, Pío. El Árbol de la Ciencia. Madrid: Biblioteca Re nacimiento, I9I I.

Baroja, Pío. Youth and Egolatry. New York: A. A. Knopf, I920.

Barsh, Russel Lawrence. “Contemporary Marxist Theory and Native American Reality.” American Indian Quarterly I 2, no. 3 (I988): I 87-2II.

Beadle, Phil. "Interview: Ben Walden 'Once More Unto the Teach...”' Shakespeare 6 (20I 5): 44-47.

Bey, Hakim. T.A.Z.: The Temporary Autonomous Zone, Ontological Anarchism, Poetic Terrorism. (2nd Edition). New York: Autonomedia, [1985] 2003.

Bhattacharya, Deben (Trans.). The Mirror of the Sky: Songs of the Bāuls of Bengal. Prescott, AZ: Hohm Press, I999.

Bohm, David. Wholeness and the Implicate Order. London: Routledge \& Kegan Paul, I980.

Boitani, Piero. "Introduction to Prosatori Negri Americani del Novecento, Translated by Patrick Brancaccio." Colby Library Quarterly I5, no. 4 (I979): 210-223. 
Bookchin, Murray. Social Anarchism or Lifestyle Anarchism: An Unbridgeable Chasm. Edinburgh and San Francisco: AK Press, I995.

Bouthoul, Betty. Le Grand Maître des Assassins. Paris: Armand Colin, 1936.

Boyette, Michael and Randi Boyette. "Let It Burn!": The Philadelphia Tragedy. Chicago: Contemporary Books, I989.

Briquelet, Kate. "Lakota Warriors Vow to Crush Dirty Rainbow Hippies." The Daily Beast. 20 June 201 5 . https://www.thedailybeast.com/lakota-warriors-vow-to-crush-dirty-rainbow-hippies

British Medical Bulletin. "Annotations \& News: Despotism in the Family." British Medical Bulletin 5, no. 2-3 (I947): 248-249.

Butler, Shane. Benign Anarchy: Alcoholics Anonymous in Ireland. Dublin: Irish Academic Press, 20 Iо.

Cafard, Max. "AnarChapters: Zhuangzi's Crazy Wisdom \& Da(o) $\mathrm{Da}(\mathrm{o})$ Spirituality." Fifth Estate 37, no. 4 (2003): 20-25.

Canby, Henry Seidel. “American Literature.” In The Encyclopaedia Britannica, I4th Ed. Vol. I. Edited by J. L. Garvin, 784-796. London: Encyclopaedia Britannica Co., I929.

Cannon, Patrick. "Martin Buber \& Leo Tolstoy: Two Examples of Spiritual Anarchism." Philosophy Now I I 6 (2016): I6-I 8.

Carrette, Jeremy and Richard King. Selling Spirituality: The Silent Takeover of Religion. London and New York: Routledge, 2005.

Carrington, Damian. "Plummeting Insect Numbers 'Threaten Collapse of Nature"." The Guardian. Io February 2019. Available at: https://www.theguardian.com/environment/20I 9/feb/Io/ plummeting-insect-numbers-threaten-collapse-of-nature

Carter, Lewis F. Charisma and Control in Rajneeshpuram: The Role of Shared Values in the Creation of a Community. Cambridge: Cambridge University Press, I990.

Chakraborty, S. K. "Editorial: From Intellectual Anarchism to Spiritual Anarchism." Journal of Human Values 3, no. I (I997): I-2.

Chomsky, Noam. The Common Good. Berkeley, Odonian Press, I998.

Chomsky, Noam. On Anarchism. New York and London: The New Press, 20I3. 
Christian, David. “Scales.” In Hughes-Warrington, Marnie (Ed.). World Histories. 64-89. New York: Palgrave Macmillan, 2005.

Christoyannopoulos, Alexandre. Christian Anarchism: A Political Commentary on the Gospel (Abridged edition). Exeter: Imprint Academic, 20I I.

Christoyannopoulos, Alexandre \& Matthew S. Adams. "Anarchism and Religion: Exploring Definitions." In Essays in Anarchism and Religion: Volume 2. Edited by Alexandre Christoyannopoulos and Matthew S. Adams, I-I9. Stockholm: Stockholm University Press, 2018.

Clarke, Bruce. Dora Marsden and Early Modernism: Gender, Individualism, Science. Ann Arbor: University of Michigan Press, I996.

Clark, John. The Anarchist Moment: Reflections on Culture, Nature and Power. Montréal: Black Rose Books, I984. de Cleyre, Voltairine. Selected Works of Voltairine de Cleyre: Pioneer of Women's Liberation. New York: Revisionist Press, [I9I4] 1972.

Cohn, Norman. Pursuit of the Millennium: Revolutionary Millenarians and Mystical Anarchists of the Middle Ages (Revised and Expanded Edition). New York: Oxford University Press, [I957] I970.

Coon, Deborah J. "'One Moment in the World's Salvation': Anarchism and the Radicalization of William James." The Journal of American History 83, no. I (I996): 70-99.

Crass, Chris. Collective Liberation on my Mind. Montreal: Kersplebedeb, 200I.

CrimethInc. "\# I 5: The Ex-Worker Holiday Special: Anarchist Perspectives on Religion, Morality, God, and Atheism." 20I3. Available at: https://crimethinc.com/podcasts/the-ex-worker/episodes/I 5

Critchley, Simon. "Mystical Anarchism.” Critical Horizons ı, no. 2 (2009): 272-306.

Crone, Patricia. "Ninth-Century Muslim Anarchists." Past and Present, no. I 67 (2000): 3-28.

Crowley, Aleister. The Commentaries of AL: The Equinox Vol. V No I. Marcelo Ramos (ed.). New York: Samuel Weiser, I975. 
Cuda, John. Re-Enchanting the Social-Identity Transformation, Embodiment, and Prefigurative Religious Practices in New Spirituality Culture. Ph.D. Dissertation, University of Pittsburgh, 2017.

Cudenec, Paul. The Anarchist Revelation. Sussex: Winter Oaks Press, 20I3.

Curtis, Edward E. and Danielle Brune Sigler (Eds.). The New Black Gods: Arthur Huff Fauset and the Study of African American Religions. Bloomington, IN: Indiana University Press, 2009.

Cypher, Jay. "Anarchy As Spiritual Practice.” Posted by PracticalAnarchyTV. 24 January 20I4. https://www.youtube.com/ watch?v=J2qDq1 5 SGHY

Davis, Erik. Nomad Codes: Adventures in Modern Esoterica. Portland: Verse Chorus Press, 20 IO.

Dewey, Clayton. "Anarchism and Unitarian Universalism." The Anarchist Library. 2004.

Dolgoff, Sam (Ed.). Bakunin on Anarchism. Montréal: Black Rose, 2002.

Dowman, Keith. Masters of Mahamudra: Songs and Histories of the Eighty-Four Buddhist Siddhas. Albany: SUNY Press, I 985.

Du Bois, W. E. B. Dark Princess: A Romance. Jackson, MS: Banner Books/University Press of Mississippi, [1928] 1995.

Edmonds, Ennis Barrington. Rastafari: From Outcasts to Culture Bearers. Oxford and New York: Oxford University Press, 2003.

Eagleton, Terry. On Evil. New Haven and London: Yale University Press, 2010.

Eneix, Travis. "Why I am a Spiritual Anarchist?" Travis Eneix: Culture is not your friend. Know your dose. 20I7 Available at: http://www.traviseneix.com/tag/random/

Epps, Garrett. To an Unknown God: Religious Freedom on Trial. New York: St. Martin's Press, 200I.

Evening Star. "Blavatsky's Alleged Tricks." Evening Star 22 June, (I889): I I. 
Faust, Saint. "The Magician as Spiritual Anarchist." Online document. n.d. (Uploaded 2008). Available at: https://www.scribd.com/ document $/ 7823897 /$ Spiritual-Anarchist

Faxneld, Per. "Witches, Anarchism and Evolutionism: Stanislaw Przybyszewski's fin-de-siècle Satanism and the Demonic Feminine." In The Devil's Party: Satanism in Modernity. Edited by Per Faxneld and Jesper Aagaard Petersen, 53-77. New York and Oxford: Oxford University Press, $20 \mathrm{I} 2$.

Feldt, Alex. "Governing Through the Dao: A Non-Anarchistic Interpretation of the Laozi." Dao 9 (2010): 323-337.

Fernée, Tadd Graham. "Methodological Revolutions in 2oth Century History and Literature: Time Consciousness and Perceptions of Power." In S. Bogdanov (Ed.), Tradition as Inspiration, 23-53. Sofia: New Bulgarian University, 20I4.

Fiscella, Anthony T. "From Muslim Punks to Taqwacore: An Incomplete History of Punk Islam.” Contemporary Islam 6 (20I2): 25 5-28I.

Fiscella, Anthony T. “Universal Burdens: Stories of (Un)freedom from the Unitarian Universalist Association, The MOVE Organization, and Taqwacore." Ph.D. Dissertation. Lund University, 2015.

Fiscella, Anthony T. "Removing MOVE: A Case Study of Intersectional Invisibility within Religious and Legal Studies." International Journal for the Study of New Religions 7, no. I (20I6): 3-4I.

Fitch, Noel. Anaïs: The Erotic Life of Anaïs Nin. Boston: Back Bay, 1993.

Fitzgerald, Timothy. Discourse on Civility and Barbarity: A Critical History of Religion and Related Categories. Oxford and New York: Oxford University Press, 2007.

Forbes, Jack D. "Indigenous Americans: Spirituality and Ecos." Daedalus I30, no. 4 (200I): 283-300.

Forbes, Jack D. Columbus and Other Cannibals [revised edition]. New York: Seven Stories Press, [1979] 2008.

Foster, Thomas W. "American Culture Through Amish Eyes: Perspectives of an Anarchist Protest Movement." MARS/Social Thought and Research 20, no. I-2 (I997): 89-108. 
Fox, Dennis R. "Anarchism and Psychology." Theory in Action 4, no. 4 (2OII): $3 \mathrm{I}-48$.

Fox, Michael W. Bringing Life to Ethics: Global Bioethics for a Humane Society. Albany: State University of New York Press, 200I.

Freeborne, Wylden. "Towards an Anarchist Spirituality." This is Primal War. 20 September 20I I. http://thisisprimalwar.blogspot. com/20I I/06/towards-anarchist-spirituality.html

Fuglestad, Finn. The Ambiguities of History: The Problem of Ethnocentrism in Historical Writing. Oslo: Oslo Academic Press, 2005 .

Galván-Álvarez, Enrique. "Why Anarchists Like Zen? A Libertarian Reading of Shinran (I I 73-I 263)." In Christoyannopoulos, A. and Adams, M. S. (eds.) Essays in Anarchism and Religion: Volume I, 78-123. Stockholm: Stockholm University Press, 2017.

Gangloff, Mike. "GG Speaks: GG Allin, May I3, I993.” Richmond City Paper. 6 June (1993): I7.

Gauffin, Axel. Ivan Aguéli: Människan-Mystikern-Målaren. 2 vol. Stockholm, I940-I94I.

Geiger, John. Nothing is True Everything is Permitted: The Life of Brion Gysin. New York: Disinformation, 2005.

Ghosh, Aurobindo. "The Renaissance in India (I9I8)." In Indian Philosophy in English: From Renaissance to Independence. Edited by Nalini Bhushan, Jay L. Garfield, 37-66. Oxford and New York: Oxford University Press, 20I I.

Gilden, Andrew. "Preserving the Seeds of Gender Fluidity: Tribal Courts and the Berdache Tradition." Michigan Journal of Gender and Law I3, no. 2 (2006): 237-272.

Gilio-Whitaker, Dina. As Long as Grass Grows: The Indigenous Fight for Environmental Justice, from Colonization to Standing Rock. Boston: Beacon Press, 2019.

Gleaves, Edwin S. "Hemingway and Baroja: Studies in Spiritual Anarchism." Revista de Estudios Hispánicos 5, no. 3 (I97I): $363-375$.

Goffman, Ken and Dan Joy. Counterculture Through the Ages: From Abraham to Acid House. New York: Random House, 2004. 
Goodway, David. Anarchist Seeds beneath the Snow: Left Libertarian Thought and British Writers from William Morris to Colin Ward. Oakland, CA: PM Press, 20I I.

Gopal, Madan. "Krishnamurti and Spirituality: A Comment on Wren-Lewis's View." Journal of Humanistic Psychology 35, no. I (1995): 89-96.

Graeber, David. Fragments of an Anarchist Anthropology. Prickly Paradigm Press, Chicago, 2004.

Green Anarchy. "There Is No Authority But Yourself: Reclaiming J. Krishnamurti for Anarchy." Green Anarchy 20 (2005): IO-I3.

Green, Martin. Mountain of Truth: The Counterculture Begins, Ascona, I900-1920. Hanover, NH: University Press of New England, I986.

Greer, Joseph Christian. “Occult Origins: Hakim Bey's Ontological Post-Anarchism." Anarchist Developments in Cultural Studies 2, (20I3): I66-I 87 .

Griffin, Farah Jasmine. "Black Feminists and Du Bois: Respectability, Protection, and Beyond." The Annals of the American Academy of Political and Social Science 568, no. I (2000): 28-40.

Gross, Naomi. "A Historical Comparison of Anabaptism to Anarchism: To What Extent do the Swiss Brethren Embody the Ideals of Spiritual Anarchism?" Newsletter of the Mennonite Historical Society of Alberta I6, no. 3 (2013): I 8-23.

Hahn, Miriam. Playing Hippies and Indians: Acts of Cultural Colonization in the Theatre of the American Counterculture. Ph.D. Dissertation. Bowling Green State University, 20I4.

Harrison, Frederic. Realities and Ideals. London: Macmillan Company, I908.

Harrison, Renee K. Enslaved Women and the Art of Resistance in Antebellum America. New York: Palgrave Macmillan, 2009.

Hauptman, Laurence M. "The American Indian Federation and the Indian New Deal: A Reinterpretation.” Pacific Historical Review 52, no. 4 (I983): 378-402.

Harvey, Larry. "How The West Was Won: Anarchy Vs. Civic Responsibility." The Burning Man Journal. I2 November 
20I3. Available at: https://journal.burningman.org/2013/II/ philosophical-center/ten principles/how-the-west-was-wonanarchy-vs-civic-responsibility/

Heat-Moon, William Least. Blue Highways: A Journey into America. Boston: Back Bay, I999.

Heckert, Jamie. "An Other State of Mind is Possible: Anarchism and Psychology." Social and Personality Psychology Compass 7, no. 8 (20I3): 5I3-525.

Heelas, Paul and Linda Woodhead. The Spiritual Revolution: Why Religion is Giving Way to Spirituality. Oxford: Blackwell Publishing, 2005 .

Hellman, Ben. Poets of Hope and Despair: The Russian Symbolists in War and Revolution, I9I4-I9I8. Leiden: Brill, 2018.

Helms, Robert. "Leaving Out the Ugly Part-On Hakim Bey." The AnarchistLibrary, 2004.Availableat:https:/theanarchistlibrary.org/ library/robert-p-helms-leaving-out-the-ugly-part-on-hakim-bey

Henderson, Archibald. European Dramatists. Stewart \& Kidd Company, I9r 8.

Herve. “Spiritual Anarchism.” MEtheSIDEWALKandGOD. 2 I July 20 I 5. Available at: https://www.youtube.com/watch?v=GOQyXT2BEbE

Höjer,Henrik."MötMattiasGardell-HedningenSomFörsvararPolitisk Islam.” Forskning \& Framsteg 2, 2007. https://fof.se/tidning/2007/2/ artikel/mot-mattias-gardell-hedningen-som-forsvarar-politisk-islam

Hoppen, Franziska. "A Reflection on Mystical Anarchism in the Works of Gustav Landauer and Eric Voegelin.” In: Christoyannopolous, A. and Adams, M. (eds.) Essays in Anarchism and Religion: Volume I, I98-237. Stockholm: Stockholm University Press, 2017.

Hubbard, LaRese. "Frances Ellen Watkins Harper: A Proto-Africana Womanist.” Western Journal of Black Studies 36, no. I (20I2): 68-75.

Iliopoulos, Christos. Nietzsche \& Anarchism: An Elective Affinity, and a Nietzschean reading of the December o8 Revolt in Athens. Ph.D. Dissertation. Loughborough University, 2014.

Jayakar, Pupul. J. Krishnamurti: A Biography. London: Arkana/ Penguin Books, 1986. 
Jean-Veneuse, Mohamed. Anarca-Islam. Anarchist Library, 2009. Available at: https://theanarchistlibrary.org/library/mohamed-jeanveneuse-anarca-islam

Jenson, Matt and David E. Wilhite. The Church: A Guide for the Perplexed. London and New York: Bloomsbury T \& T Clark, 20 Iо. jones, pattrice. "Free as a Bird: Natural Anarchism in Action." In Contemporary Anarchist Studies. Edited by Randall Amster, Abraham DeLeon, Luis A. Fernandez, Anthony J. Nocella II, and Deric Shannon, 236-246. London and New York: Routledge, 2009.

Jouhki, Jukka. Imagining the Other: Orientalism and Occidentalism in Tamil-European Relations in South India. Jyväskylä: University of Jyväskylä, 2006.

Karamustafa, Ahmet T. God's Unruly Friends: Dervish Groups in the Islamic Middle Period I200-I 550. Oxford: Oneworld, 2006.

Kazmi, Zaheer. "Automatic Islam: Divine Anarchy and the Machines of God.” Modern Intellectual History I 2, no. I (201 5): 33-64.

Keenan, David. England's Hidden Reverse: A Secret History of the Esoteric Underground. London: SAF publishing, 2003.

Kellogg III, E. W. and D. David Bourland, Jr. "Working with E-Prime: Some Practical Notes.” In To Be or Not: An E-Prime Anthology. Edited by D. David Bourland, Jr. \& Paul Dennithorne Johnston, 37-58. San Francisco: International Society for General Semantics, I99I.

Kelly, John F. and M. Claire Greene. "Toward an Enhanced Understanding of the Psychological Mechanisms by which Spirituality Aids Recovery in Alcoholics Anonymous." Alcoholism Treatment Quarterly 32, no. 2-3 (20I4): 299-3 I8.

Kennedy, Karen. Deeply Felt: Reflections on Religion \& Violence within the Anarchist Turn. Sparsnäs, Sweden: Irene Publishing, 2015.

Khalfaoui, Mouez. "Indian Architecture: Social and Political Challenges." Language, Communication, Information 4, (2009): 8I-94.

Kim, David Haekwon. "Modern Order and the Promise of Anarchy: From the 'Writhing Age' of Souls to World Reconstruction." Hamline Review 28, (2004): 22-7I. 
King, Richard. Orientalism and Religion: Postcolonial Theory, India, and the 'Mystic East'. New York and London: Routledge, I999.

Knight, Michael Muhammad. The Five Percenters: Islam, Hip Hop, and the Gods of New York. Oxford: Oneworld, 2007.

Knight, Michael Muhammad. William S. Burroughs Vs. the Quran. Berkeley: Soft Skull Press, 2012.

Knight, Michael Muhammad. "Lifting Up My Skirt.” VICE Magazine I2 February 20I3. http://www.vice.com/read/lifting-up-my-skirt

Knowles, Rob. “'Human Light': The Mystical Religion of Mikhail Bakunin.” The European Legacy 7, no. I (2002): 7-24.

Krishnamurti, Jiddu. Think on These Things. New York: Harper \& Row, 1970.

Krishnamurti, Y.G. The Betrayal of Freedom. Bombay: The Popular Book Depot, I944.

Kropotkin, Peter. Mutual Aid: A Factor in Evolution. London: Freedom Press, [1902] 1987.

Kursions, Mia X. "Meditation on Mediation: Direct Experience as Spirituality." Green Anarchy 20, 2005. http://theanarchistlibrary. org/library/mia-x-kursions-meditation-on-mediation-direct-experience-as-spirituality.pdf

Kurtz, Ernest. Not-God: A History of Alcoholics Anonymous. Center City, MN: Hazelden, I979.

Ladha, Alnoor. "Mystical Anarchism: A Journey to the Borderlands of Freedom.” Kosmos I 5, no. I (201 5): 24-29.

Lagalisse, Erica Michelle. “'Marginalizing Magdalena': Intersections of Gender and the Secular in Anarchoindigenist Solidarity Activism.” Signs 36, no. 3 (201 I): 653-678.

Lagalisse, Erica. "Occult Features of Anarchism." In: Christoyannopoulos, A. and Adams, M. S. (eds.) Essays in Anarchism and Religion: Volume II, 278-332. Stockholm: Stockholm University Press, 2018.

Landauer, Gustav. Revolution and Other Writings. Edited and translated by Gabriel Kuhn. Oakland: PM Press, 20 Iо. 
Levy, Leonard W. Blasphemy: Verbal Offense Against the Sacred, from Moses to Salman Rushdie. Chapel Hill and London: UNC Press, I995.

Lindquist, Galina. "Meanings and Identities." In Shamanism: Critical Concepts in Sociology. Edited by Andrei A. Znamenski, 86-I I3. London and New York: RoutledgeCurzon, [1997] 2004.

Littlewood, Roland. Pathology and Identity: The Work of Mother Earth in Trinidad. Cambridge: Cambridge University Press, 2006.

Lorenzo, J. Tato. “Gotas de Miel y Ajenjo.” Solidaridad Obrera I6, no. 785,7 (I960): I.

Magid, Shaul. "Defining Christianity and Judaism from the Perspective of Religious Anarchy: Martin Buber on Jesus and the Ba'al Shem Tov." Journal of Jewish Thought \& Philosophy 25 (20I7): $36-58$.

Malatesta, Errico. "Pro-Government Anarchists." Freedom I9I6. Republished in Malatesta: His Life and Ideas. Edited by Vernon Richards, 248-25 I. London: Freedom Press, 1977.

Martinito, Mr. "What is Spiritual Anarchism?" Spiritual Anarchism: Thoughts on grassroots spirituality and other abominable heresies. I5 January 2008 Available at: http://spiritualanarchism.blogspot.com/2008/oI/what-is-spiritual-anarchism.html

Marshall, Peter. Demanding the Impossible: A History of Anarchism. Oakland, CA: PM Press, [1992] 2010.

Martín-Baró, I. Writings for a Liberation Psychology. Essays, 1985-1989 (Edited by A. Aron, and S. Corne). Cambridge, MA: Harvard University Press, I994.

Mattis, Jacqueline S. and Robert J. Jagers. "A Relational Framework for the Study of Religiosity and Spirituality in the Lives of African Americans." Journal of Community Psychology 29, no. 5 (2001): 519-539.

Maurer, Charles B. Call to Revolution: The Mystical Anarchism of Gustav Landaner. Detroit: Wayne State University Press, I97I.

May, Vivian M. "Under-Theorized and Under-Taught: Re-examining Harriet Tubman's Place in Women's Studies.” Meridians I 2, no. 2 (20I4): 28-49. 
Mayer, Gerhard A. "The Figure of the Shaman as a Modern Myth: Some Reflections on the Attractiveness of Shamanism in Modern Societies." The Pomegranate Io, no. I (2008): 70-103.

Mazura, Ondřej. An Anarchist Concept of God. Bachelor's Thesis, Prague: Univerzita Karlova, 2017.

MacDonald, Charles. "The Anthropology of Anarchy." Indian Journal of Human Development 6, no. I (201 2): 49-66.

McDowell, Amy D. "This is for the Brown Kids!: Racialization and the Formation of 'Muslim' Punk Rock.” Sociology of Race and Ethnicity 3, no. 2 (2017): I 59-I7I.

McKanan, Dan. Prophetic Encounters: Religion and the American Radical Tradition. Boston: Beacon Press, 20I I.

McNicholl, Adeana. "Being Buddha, Staying Woke: Racial Formation in Black Buddhist Writing." Journal of the American Academy of Religion 86, no. 4 (2018): 883-9II.

Means, Russell. "Fighting Words for the Future of the Earth." In Questioning Technology, edited by John Zerzan and Alice Carnes, 7I-82. Philadelphia, PA and Gabriola Island, BC: New Society Publishers, I99I.

Mendiola, Fernando. "Cogs in the Military Machine? War Experience and Antimilitarism during the Spanish Civil War." Workers of the World I, no. 6 (201 5): 6-28.

Milner, Clyde A. With Good Intentions: Quaker Work among the Pawnees, Otos, and Omahas in the I870s. Lincoln and London: University of Nebraska Press, I982.

Minor, Robert N. The Religious, the Spiritual and the Secular: Auroville and Secular India. Albany: State University of New York Press, I999.

Mitchell, J. Lawrence. "Poet of Passionate Friendship': Walt Whitman, John Cowper Powys \& Katie Powys.” The Powys Journal 25 (2OI 5): I 23-I38, 244.

Moane, Geraldine. "Bridging the Personal and the Political: Practices for a Liberation Psychology." American Journal of Community Psychology 3I, nos. I/2, (2003): 9I-IOI. 
Mohammada, Malika. The Foundations of the Composite Culture in India. Delhi: Aakar Books, 2007.

Moore, John. Anarchy and Ecstasy: Visions of Halcyon Days. London: Aporia Press, I988.

Morris, Brian. Ecology and Anarchism. Worcestershire: Images Publishing, 1996.

Morrison-Reed, Mark. Darkening the Doorways: Black Trailblazers and Missed Opportunities in Unitarian Universalism. Edited by Mark Morrison-Reed. Boston: Skinner House Books, 20I I.

Mother Earth. "Observations and Comments." Mother Earth 8, no. 7 (I913): I96-197.

Mueller, Marti. "Spirituality in Auroville, India.” In Ecovillage Living: Restoring the Earth and Her People. Edited by Hildur Jackson and Karen Svensson, I I I-I I 3. Totnes: Green Books, I990.

Murray, William J. Anarchic Harmony: The Spirituality of Social Disobedience. Port Townsend, WA: Loompanics Unlimited, I992.

Nalimov, V. V. "On the History of Mystical Anarchism in Russia." International Journal of Transpersonal Studies 20, no. I, (200I): $85-98$.

Namakkal, Jessica. "European Dreams, Tamil Land: Auroville and the Paradox of a Postcolonial Utopia." Journal for the Study of Radicalism 6, no. I (2012): 59-88.

Nance, Susan. "Mystery of the Moorish Science Temple: Southern Blacks and American Alternative Spirituality in I920s Chicago." Religion and American Culture I2, no. 2 (2002): I23-I 66.

Nash, Roderick Frazier. The Rights of Nature: A History of Environmental Ethics. The Madison: University of Wisconsin Press, I989.

Newman, Saul. "Voluntary Servitude Reconsidered: Radical Politics and the Problem of Self-Domination." Anarchist Developments in Cultural Studies I (20I0): 3 I-49.

Nickleberry. "ASCM and Anarchist Spirituality." Nickleberry. 20 February 20II. http://nickleberry-huxtable.blogspot.com/20I I/ o2/ascm-and-anarchist-spirituality.html 
Nietzsche, Friedrich. Also sprach Zarathustra. Chemnitz, Germany: Verlag von Ernst Schmeitzner, I883-I 885 .

Nishida, Tenko. Life of Ittoen: A New Road to Ancient Truth. Kyoto: Ittoen Publishing House, I983.

Noesta, Waldo. "Introduction to Spiritual Anarchism." Not Two. 9 June 20I9. Available at: https://nondualmedia.org/2019/06/09/ introduction-to-spiritual-anarchism/

Okulski, Juliana E. "Complex Adaptive Peacemaking: How Systems Theory Reveals Advantages of Traditional Tribal Dispute Resolution." American Indian Law Journal 5, no. I (201 7): 263-307.

O’Regan. David. “Jiddu Krishnamurti’s Influence on Bruce Lee and Popular Martial Arts Culture." Journal of Asian Martial Arts I4, no. I (2005): 9-25.

Otherworlds Review. "Otherworlds Review \#7: Spiritual Anarchism.” It's Going Down. 20I8. https://itsgoingdown.org/ otherworlds-review-7-spiritual-anarchism/

Peat, F. David. Blackfoot Physics: A Journey into the Native American Worldview. Boston: Red Wheel/Weiser, 2002.

Peele, Stanton, Charles Bufe, and Archie Brodsky. Resisting I2-Step Coercion: How to Fight Forced Participation in AA, NA, or the I2-Step Treatment. Tucson: See Sharp Press, 2000.

Perry, Lewis. Radical Abolitionism: Anarchy and the Government of God in Antislavery Thought. Knoxville: University of Tennessee Press, [1973] I995.

Phillips, Layli. The Womanist Reader. New York: Routledge, Taylor \& Francis, 2006.

Pignataro, Anthony. “The Spiritual Maverick.” Maui Time 7, no 20 (2003): 20.

Preparata, Guido Giacomo. "Perishable Money in a Threefold Commonwealth: Rudolf Steiner and the Social Economics of an Anarchist Utopia." Review of Radical Political Economics 38, (2006): 619-648.

Quan, H.L.T. "Emancipatory Social Inquiry: Democratic Anarchism and the Robinsonian Method." African Identities I I, no. 2 (20I3): I I 7-I 32 . 
Queluz, Gilson Leandro. "“Comrade Krishnamurti’: Brazilian Anarchist Press and Krishnamurti's trip to Brazil in 1935.” Paper presented at Anarchist Studies Network Conference, I4 September. Loughborough University, 2018.

Raaij, André de. "Parallels or Influence: The Dutch Christian Anarchist Movement I897-I907 and the Landauer Connection.” A Pinch of Salt. 2 I July 2009. Available at: http://www.apinchofsalt.org/2009/o7/parallels-or-influence-dutch-christian.html

Rambachan, Anantanand. The Limits of Scripture: Vivekananda's Reinterpretation of the Vedas. Honolulu: University of Hawaii Press, I994.

Ramnath, Maia. Decolonizing Anarchism: An Antiauthoritarian History of India's Liberation Struggle. Oakland: AK Press/Institute for Anarchist Studies, 20I I.

Rapp, John A. Daoism and Anarchism: Critiques of State Autonomy in Ancient and Modern China. New York and London: Continuum, 2012.

Razak, Arisika. "Embodying Womanism: Notes Toward a Holistic and Liberating Pedagogy." In Ain't I a Womanist Too? Third Wave Womanist Religious Thought. Edited by Monica A. Coleman, 217-229. Minneapolis: Fortress Press, 2013.

Read, James H. "The Limits of Self-Reliance: Emerson, Slavery, and Abolition." Paper presented to the annual meeting of the American Political Science Association, Toronto, Ontario, 3-6 September, 2009.

Riley, Danny. "Ascent Is Immanent: The Strange World Of Ben Chasny." The Quietus. 22 February 20I7. https://thequietus.com/ articles/2 I 840-ben-chasny-six-organs-of-admittance-comets-onfire-interview

Robinson, Cedric. The Terms of Order: Political Science and the Myth of Leadership. Albany: State University of New York Press, I980.

Ronan, Anna. “Anarchism as a Spiritual Practice.” Paper at DSA Libertarian Socialist Caucus. 23 May (20I9): I-IO. Available at: https://dsa-lsc.org/20I 9/05/24/anarchism-as-a-spiritual-practice-2/

Rosenberg, Marshall. Non-Violent Communication: A Language of Life. Encinitas, CA: PuddleDancer Press, 2003. 
Rosenthal, Bernice Glatzer. "The Transmutation of the Symbolist Ethos: Mystical Anarchism and the Revolution of 1905." Slavic Review 36, no. 4 (I977): 608-627.

Rubiner, Joanna. "Harper, Frances Ellen Watkins.” Contemporary Black Biography. I996. http://www.encyclopedia.com/topic/ Frances_Ellen_Watkins_Harper.aspx

Sadr, Jessica Spain. "Natural Anarchism and Ecowomanism: Crafting Coalition-based Ecological Praxis." Green Theory and Praxis 7, no. I (2OI3): I7-25.

Said, Edward W. Orientalism. New York: Vintage, I979.

Sala, Ronald W. "Hidden Unitarian Universalist Roots: Ties with Hermeticism and Freemasonry." In Unitarian Universalist Ministers' Association: Selected Essays, edited by A. Payson and K. Payson, I6I-I75. Boston: Unitarian Universalist Ministers' Association, 2000.

Sánchez-Bayo, Francisco and Kris A. G. Wyckhuys. "Worldwide Decline of the Entomofauna: A Review of its Drivers." Biological Conservation 232 (2019): 8-27.

Sargisson, Lucy and Lyman Tower Sargent. Living in Utopia: New Zealand's Intentional Communities. Burlington, VT and Hants, UK: Ashgate Publishing Group, 2004.

Sarracino, Carmine Thomas. Henry Miller, Spiritual Anarchist. Ph.D. Dissertation. University of Michigan, I974.

Schouten, Jan Peter. Revolution of the Mystics: On the Social Aspects of Vìraśaivism. Kampen, Netherlands: Kok Pharos Publishing House, I99I.

Schmidt, Michael, and Lucien van der Walt. Black Flame: The Revolutionary Class Politics of Anarchism and Syndicalism. Oakland: AK Press, 2009.

Sehulster, Patricia J. "Frances Harper's Religion of Responsibility in Sowing and Reaping." Journal of Black Studies 40, no. 6 (2010): II 36 -II 52 .

Sesay Jr., Chernoh M. "The Dialectic of Representation: Black Freemasonry, the Black Public, and Black Historiography." Journal of African American Studies I7 (2013): 380-398. 
Shapira, Amnon. Jewish Religious Anarchism: Or: Does The Jewish Religion Sanctify State Rule? Self-published, 2013. Available at: https://www.academia.edu/427I 769/Religious_Jewish_Anarchism

Smith, Huston. A Seat at the Table: Huston Smith in Conversation with Native Americans on Religious Freedom. Berkeley: University of California Press, 2007.

Snyder, Gary. "Buddhist Anarchism." Fifth Estate 37, no. 4 ([I96I] 2003): 20-25.

Soper, Kate. "On Human Nature: Noam Chomsky interviewed by Kate Soper.” Red Pepper. I998. http://www.chomsky.info/interviews/I99808--.htm

Spence, Richard. "Secret Agent 666: Aleister Crowley and British Intelligence in America, I9I4-I9I8." International Journal of Intelligence and CounterIntelligence $\mathrm{I} 3$, no. 3 (2000): 359-37 I.

Springer, Ruter W. "Gives the Snap Away." [letter to the editor] BlueGrass Blade 7 June, I908.

St. Louis Republic. "Meetings May Result in New Church Organization.” St. Louis Republic Io February (I902): Io.

Stack, George J. Nietzsche and Emerson: An Elective Affinity. Athens: Ohio University Press, I992.

Stallings-Ward, Judith. "Imaging Satyagraha: The Personal Effects of Buenaventura Durruti and Mahatma Gandhi." The International Journal of the Image I, no. 2 (201 I): I85-196.

Starhawk. Truth or Dare: Encounters of Power, Authority, Mystery. San Francisco: Harper \& Row, I988.

Stendardo, Luigi. Leo Tolstoy and the Bahái Faith. Translated by Jeremy Fox. Oxford: George Ronald, 1985.

Stewart, Francis. Punk Rock is my Religion: Straight Edge Punk and 'Religious' Identity. London and New York: Routledge, 2017.

Sunshine, Spencer. "Rebranding Fascism: National Anarchists." The Public Eye. 28 January 2008. http://www.politicalresearch. org/2008/or/28/rebranding-fascism-national-anarchists

TallBear, Kim. "Why Interspecies Thinking Needs Indigenous Standpoints." Cultural Anthropology. 24 April 20II. https:// 
culanth.org/fieldsights/260-why-interspecies-thinking-needs-indigenous-standpoints

Taylor, Bron. "Gary Snyder." In Encyclopedia of Religion and Nature. Edited by Bron Taylor, I 562-I 566. London \& New York: Continuum, 2005 .

Taylor, Bron. Dark Green Religion: Nature Spirituality and the Planetary Future. Berkeley, Los Angeles and London: University of California Press, 20 Io.

Thompson, Christopher Scott. Pagan Anarchism. USA: Gods\&Radicals, 2016.

Tolboll, Morten. The Matrix Conspiracy Part I. Self-published book. 20I4. Available at: http://www.MortenTolboll.blogspot.com

Tsosie, Rebecca. "Indigenous Peoples and Epistemic Injustice: Science, Ethics, and Human Rights." Washington Law Review 87 (2012): II33-I2OI.

Ueno, Toshiya. "Deleuze and Guattari and Buddhism: Toward Spiritual Anarchism through Reading Toshihiko Izutsu." In Deleuze and Buddhism. Edited by Tony See and Joff Bradley, I23-I 58. London: Palgrave Macmillan, 2016.

Underhill, Evelyn. Mysticism: A Study in the Nature and Development of Man's Spiritual Consciousness. Mineola, NY: Dover Publications, [I9II] 2002.

Upton, Charles [translator]. Doorkeeper of the Heart: Versions of Rabia. Putney, VT.: Threshold Books, I988.

Vaneigem, Raoul. The Movement of the Free Spirit. New York: Zone Books, 1998.

Varma, Vishwanath Prasad. The Political Philosophy of Sri Aurobindo. Dehli: Motilal Banarsidass, [1960] 1976.

Vengopal, Kalpana and Priya Kumari. "Auroville School and Holistic Education." Encounter: Education for Meaning and Social Justice 23 , no. 3 (2010): 59-63.

Versluis, Arthur. American Gurus: From Transcendentalism to New Age Religion. Oxford and New York. Oxford University Press, 2014. 
Veysey, Laurence. The Communal Experience: Anarchist and Mystical Counter-Cultures in America (Phoenix Edition). Chicago and London: University of Chicago Press, [1973] 1978.

Voorsanger, Jacob. Sermons and Addresses. New York: Bloch Publishing, I9I3.

Walker, Alice. In Search of Our Mothers' Gardens. Orlando: Harcourt, Inc., I983.

Walker, Christopher J. Reason and Religion in Late Seventeenthcentury England: The Politics and Theology of Radical Dissent. London and New York: IB Tauris, 2013.

Watson, David. Against the Megamachine: Essays on Empire and its Enemies. Detroit and Brooklyn: Fifth Estate and Autonomedia, I998.

Weinstein, MaxZine. "Anarcho-spirituality and its Discontents: A Personal Reflection.” Fifth Estate 37, no. 4 (2002-2003): 32.

Weltin, E. G. "Quantae Molis Erat Plebeios Fingere Christi." The Classical Journal 5 I, no. 8 (I956): 375-386.

Westermeyer, Joseph. “Alcoholics Anonymous and Spiritual Recovery: A Cultural Perspective.” Alcoholism Treatment Quarterly 32, no. 2-3 (20I4): I 57-I72.

Whyte, Iain. 'Send Back the Money!': The Free Church of Scotland and American Slavery. Cambridge: James Clarke \& Co, 20 I 2.

Wiley, Anthony Terrance. Angelic Troublemakers: Religion and Anarchism in America. New York and New Delhi: Bloomsbury, 20I4.

Wilson, Peter Lamborn. Scandal: Essays in Islamic Heresy. New York: Autonomedia, 1988.

Wilson, Peter Lamborn. Sacred Drift: Essays on the Margins of Islam. San Francisco: City Lights, I993a.

Wilson, Peter Lamborn. "Caliban's Masque: Spiritual Anarchy and the Wild Man in Colonial America." In Gone to Croatan: Origins of North American Drop Out Culture, edited by R. Sakolsky and J. Koehnline, 95-II6. Brooklyn and Edinburgh: Autonomedia and AK Press, r993b. 
Wilson, Peter Lamborn. "Spiritual Anarchism." Public lecture at Libertarian Book Club's Anarchist Forum. New York, ıo December 2002. Available at: http://www.radio4all.net/index.php/program/6 I 20

Wilson, Peter Lamborn. "Spiritual Anarchism: Topics for Research." Fifth Estate 37, no. 4 (2003): 27-29.

Wollstonecraft, Mary. A Vindication of the Rights of Woman: And, the Wrongs of Woman, Or, Maria. Edited by Anne Kostelanetz Mellor and Noelle Chao. New York: Pearson Longman, [I792] 2007.

Wretch, A. The Chronicles of Anarchy. Self-published online. No date [c. 20I7]. Available at: https://www.academia.edu/33 I 8 I $556 /$ The_Chronicles_of_Anarchy

Zein, Menna El Dawi. A Philosophy of Rebellion: Anarchism in Literature and Film. Master's thesis. American University in Cairo, 2016.

Žižka-Marušiaková, Jana. "Spiritual Anarchy in Emerson: The Infinitude of the Private Man.” Masters Thesis. Prague: Charles University, 20I 2. 